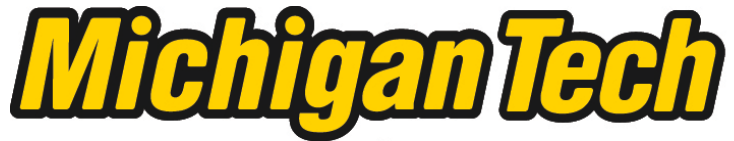 \\ Michigan Technological University Create the Future Digital Commons @ Michigan Tech
}

\section{Effects of conifer sawdust, hardwood sawdust, and peat on soil properties and a barefoot conifer seedling development}

Paul J. Koll

Michigan Technological University

Follow this and additional works at: https://digitalcommons.mtu.edu/etds

Part of the Forest Sciences Commons

Copyright 2009 Paul J. Koll

\section{Recommended Citation}

Koll, Paul J., "Effects of conifer sawdust, hardwood sawdust, and peat on soil properties and a barefoot conifer seedling development", Master's Thesis, Michigan Technological University, 2009.

https://doi.org/10.37099/mtu.dc.etds/140

Follow this and additional works at: https://digitalcommons.mtu.edu/etds

8 Part of the Forest Sciences Commons 


\section{EFFECTS OF CONIFER SAWDUST, HARDWOOD SAWDUST, AND PEAT ON SOIL PROPERTIES AND BAREROOT CONIFER SEEDLING DEVELOPMENT}

PAUL J. KOLL

A THESIS

Submitted in partial fulfillment of the requirements for a degree of MASTER OF SCIENCE IN FOREST ECOLOGY AND MANAGEMENT MICHIGAN TECHNOLOGICAL UNIVERSITY

2009 
This thesis, "Effects of conifer sawdust, hardwood sawdust, and peat amendments on soil properties and bareroot conifer seedling development," is hereby approved in partial fulfillment of the requirements for the Degree of MASTER OF SCIENCE IN FOREST ECOLOGY AND MANAGEMENT.

SCHOOL OF FOREST RESOURCES AND ENVIRONMENTAL SCIENCE

Signatures:

Thesis Advisor

Dr. Martin F. Jurgensen

Dean of School

Dr. Margaret R. Gale

Date 


\section{Acknowledgements}

I would like thank Drs. Kasten Dumroese and Martin Jurgensen for development of this project idea and for all the helpful comments along the way and in the writing process. A huge thanks to Martin for accepting the daunting task as my advisor. Also, I would like to thank Jim Pickens for his many hours explaining my statistics over and over again. I would especially like to thank the JW Toumey Nursery staff; Anthony Holland, Christy Makuck, Pete Allen, Loral Caudill, Pat Drake, Cammie Garrison, Dave Johnson, Terry Mansfield, Robert Moilenen and Michal Moilenen for their help and encouragement over the past three years. The experiences at the nursery were invaluable. Finally, I would like to thank Lynette Potvin and Ricky Choichois for their help throughout the study and their companionship over the years. 


\section{Table of Contents}

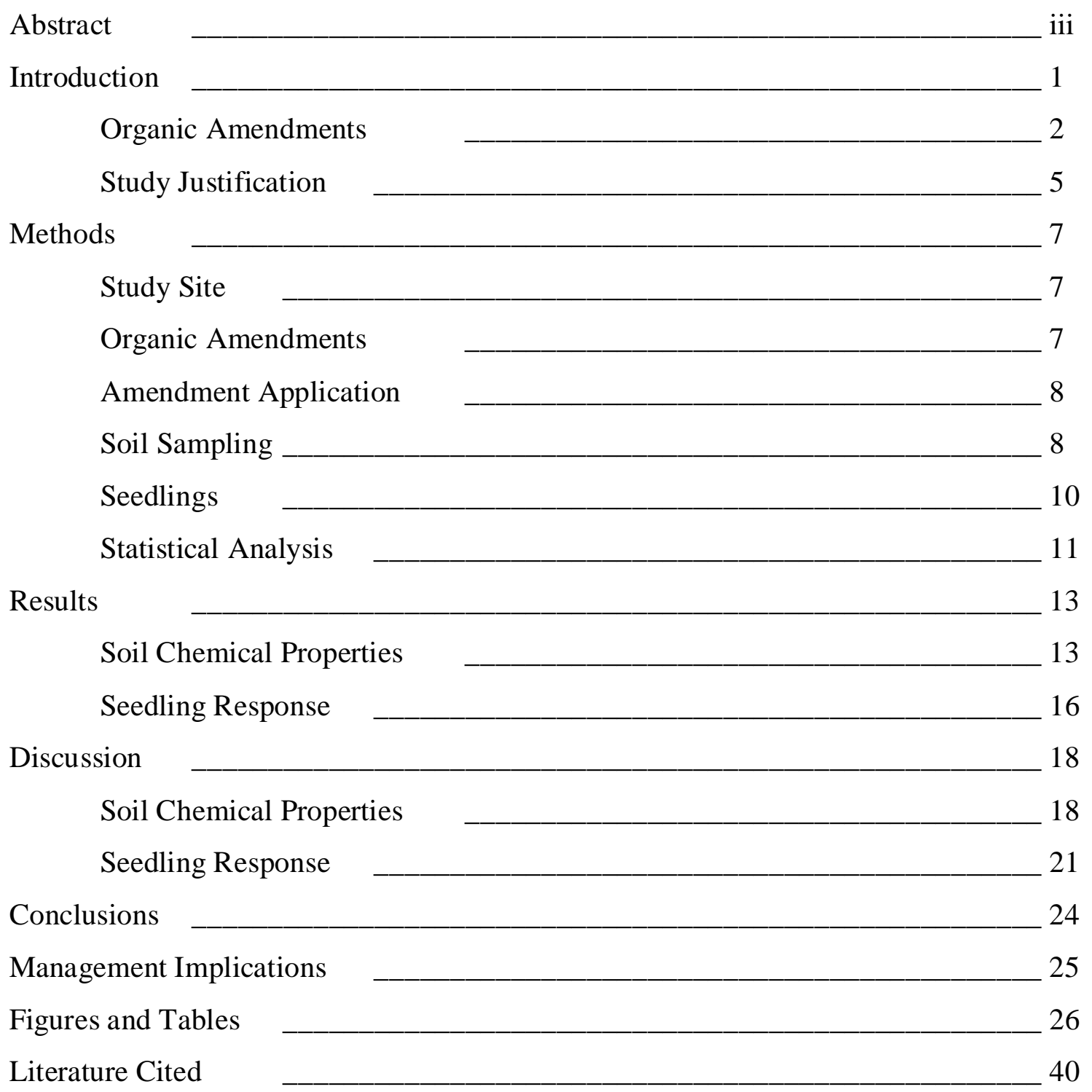




\begin{abstract}
Organic amendments are commonly used to improve tree nursery soil conditions for increased seedling growth. However, few studies compare organic amendments effects on soil conditions, and fewer compare subsequent effects on seedling growth. The effects of three organic amendments on soil properties and seedling growth were investigated at the USDA Forest Service J.W. Toumey Nursery in Watersmeet, MI. Pine sawdust (red pine, Pinus resinosa), hardwood sawdust (maple, Acer spp. and aspen, Populus spp.), and peat were individually incorporated into a loamy sand nursery soil in August, 2006, and soil properties were sampled periodically for the next 14 months. Jack (Pinus banksiana), red, and white pine (Pinus strobus) were sown into test plots in June, 2007 and sampled for growth responses at the end of the growing season. It is hypothesized; pine sawdust and peat can be used as a satisfactory soil amendment to improve soil conditions and produce high quality seedlings, when compared to hardwood sawdust in bareroot nursery soils. This study has the potential to reduce nursery costs while broadening soil amendment options.

The addition of peat and pine sawdust increased soil organic matter above control soil conditions after 14 months. However, hardwood sawdust-amended soils did not differ from control soils after same time period. High $\mathrm{N}$ concentrations in peat increased total soil N over the other treatments. Similarly, the addition of peat increased soil matric potential and available water over all other treatments. Seedlings grew tallest with the largest stem diameter, and had the largest biomass in both control soil and soil amended with peat, compared to either sawdust treatment. Seedlings grown in peat-amended soils had higher $\mathrm{N}$ concentrations than those grown in soils treated with pine sawdust, though neither was different from seedlings grown in control or hardwood sawdust-amended soils. Overall, peat is a well suited organic soil amendment for the enhancement of soil properties, but no amendments were able to increase one-year seedling growth over control soils.
\end{abstract}




\section{Introduction}

In 2000 it was estimated that $5 \%$ of the world's forests were plantations (187 million hectares), as compared to 3\% (115 million hectares) in 1995 (FAO 1999; 2001). As more native forests are cleared and farmed, it is expected that an increasing proportion of the world's supply of wood will come from plantations (Pandey and Ball 1998; Hartley 2002). Similarly, as forest management concerns are now addressing carbon (C) sequestration and biofuel production, more seedlings will be needed for reforestation efforts. Consequently, it is important to provide seedlings of the best size and quality to ensure reforestation success, while conserving the resources needed to produce them.

In the United States, 1.5 billion forest tree seedlings are produced annually (Frankel et al., 1999). Nursery managers face many problems, a survey conducted by Oregon State University in 1984 asked for the top concerns from nursery managers in the northwestern United States, and soil management was found to be paramount, especially maintenance of soil organic matter (SOM) (OSU 1984). Organic matter (OM) is rapidly depleted from tree seedling nursery soil due to entire crop harvest and rapid decomposition from intensive soil tillage (Boyer and South 1984; Riley and Steinfeld 2005; Davis et al. 2006). Proper soil maintenance by addition of OM is the best way to improve the environment for plants in nearly all soils. However, poorly-structured soils with little aggregation, which are often found in tree nurseries, can benefit the most from increases in SOM (Christopher 1996; Cogger 2005; Rentz 2005).

Numerous studies have shown that proper SOM maintenance can improve soil porosity, aggregate stability, and increase drainage, while also increasing water-holding capacity (e.g. Rose et al. 1995; Jacobs et al. 2003; Cogger 2005). Soils with adequate 
OM levels also have lower bulk densities, are more resistant to compaction, and are more workable (Rose et al. 1995; Christopher 1996). Finally, SOM increases soil nutrient content and cation exchange capacity (CEC), which minimizes leaching of soil nutrients and buffers pH fluctuations (Abd-el malek et al. 1979; Davey and Krause 1980; Mexal and Fisher 1987; Cogger 2005). Consequently, forest tree nurseries usually add organic amendments to the soil as part of routine maintenance operations.

\section{Organic Amendments}

Different OM management strategies are implemented by forest tree nurseries, depending on current and desired soil characteristics. However, many factors influence what amendment to use, such as OM type, decomposition stage, and cost. Organic amendments used in nursery soil management are of two basic types: readily-decayed and decay-resistant (Mexal and Fisher 1987). The value of an organic amendment is often rated on its carbon to nitrogen ratio (C:N) and lignin content (Cogger 2005). Many studies have looked at chemical properties of organic amendments, but few have documented plant responses to different amendments (Rose et al. 1995; Davis et al 2006). For example, Mexal and Fisher (1987) reported short, three-month increases in SOM and nutrient availability resulting from adding organic amendments, but could not discern any seedling response.

\section{Readily-Decayed Amendments}

Readily-decayed soil amendments are materials with low lignin content and C:N commonly below 30. A C:N of 30 has been shown to be the critical point, below which, 
amendments change from $\mathrm{N}$ sources to $\mathrm{N}$ sinks (Follett et al. 1981; Wolstenholme and Whiley 2002). Amendments, such as sewage or paper sludge, animal manure, and green manures, are common examples of readily-decayed organic amendments with a C:N between 10 and 30. These amendments also have low lignin content, which is an important precursor of humus, and a major component of long term SOM (Starbuck 1994; Wolstenholme and Whiley 2002). The high N content of these amendments also leads to spikes in microbial activity, and they are often completely decomposed within one year. For example, green manure added by growing an annual cover crop only increased humus content by $0.12 \%$ after 12 years (Rose et al. 1995). Consequently, longterm benefits of adding these organic amendments to nursery soils are minimal, and few nurseries use them to increase SOM or alter soil structure.

\section{Decay-Resistant Amendments}

Decay-resistant amendments (e.g. bark, sawdust, peat) have high lignin content and often high C:N values (Follett et al. 1981; Mexal and Fisher 1987). Sawdust is considered a decayed-resistant soil amendment because of its very high C:N even though it is often low in lignins (Mexal and Fisher 1987). Woody material from different tree species varies greatly. For example, $\mathrm{C}: \mathrm{N}$ ratios in sawdust can range from 134 in red alder (Alnus rubra) to as high as 1244 in western hemlock (Tsuga heterophylla) with an average around 500 (Davey 1984). However, studies on these types of organic amendments rarely identify the plant or tree species source of the material used (e.g. May and Gilmore 1985; Paustain et al. 1992). 
Sawdust is usually not recommended as a soil amendment due to its extremely high C:N ratio, yet many nurseries still commonly use it (Armson and Sandreika 1974; Williams and Hanks 1976). Roberts and Stephenson (1948) found that 7 to $10 \mathrm{~cm}$ of sawdust applied to a nursery soil caused a soil $\mathrm{N}$ deficiency for 3 to 4 years. Even at low sawdust application rates, $\mathrm{N}$ deficiencies may occur for 6 months (Allison and Anderson 1951). Such low available soil $\mathrm{N}$ levels reduce shoot volume, height, and biomass of the seedling crop (May and Gilmore 1985). Therefore, $\mathrm{N}$ fertilizer at a rate high enough to increase the amendment to a C:N near 30 is usually added (Roberts and Stephanson 1948; Allison and Anderson 1951; Landis 1984). Growing N-rich green manure crops after sawdust applications can also be used (May and Gilmore 1985). Sawdust amendments often lower nursery soil pH slightly, but usually return to pre-application levels after a year (Allison and Anderson 1951).

Peat is commonly used in small-scale nursery operations around the world (Riley and Steinfeld 2005). It is an excellent soil amendment because of its slow decomposition rates and high lignin levels, while offering a low C:N of 20 to 30 (Allison 1973). Peat is unrivaled by its ability to increase soil water retention and cation exchange capacity (CEC), which range from 60-140 kmol/kg, as compared to $13-40 \mathrm{kmol} / \mathrm{kg}$ in sawdust (Bollen 1969; Armson and Sandreika 1974). Yet, peat is rarely used as an organic amendment in barefoot tree nurseries because of its high cost and limited availability (Copperband 2002). Consequently, only a few studies have been conducted on the effect of peat applications on bareroot seedling growth (Armson and Sandreika 1974; Jacobs et al. 2003; Davis and Jacobs 2005). 


\section{Study Justification}

Declining availability and increased cost of conventional soil amendments, such as sawdust, has prompted a search for alternate sources of OM (Munson 1983, May and Gilmore 1985). For example, the USDA Forest Service J. Herbert Stone Nursery in Oregon recently explored use of yard wastes due to the rising cost of sawdust and the $\mathrm{N}$ fertilizer to supplement it (Riley and Steinfeld 2005). The USDA Forest Service J.W. Toumey Nursery, located in northern Michigan, has been using hardwood sawdust of various species as an organic amendment for more than 25 years. This sawdust was readily available from many local sawmills at little or no cost. However, with the closing of several small local mills and the demand from wood pellet companies for wood residues, sawdust prices have greatly increased (Holland 2008). In 2008, 22 tons (50 m to $61 \mathrm{~m}^{3}$ or 65 to 80 cubic yards) of hardwood sawdust delivered to the USDA Forest Service J.W. Toumey Nursery cost nearly \$1350, as compared to \$300 in 2005 (Makuck 2008). The nursery uses around $765 \mathrm{~m}^{3}$ (1000 cubic yards) of sawdust/year, which will increase sawdust costs by an estimated \$16,900 annually (Moilenen 2008).

In contrast, pine sawdust is much more abundant locally and of lower cost. Other bareroot nurseries have used pine sawdust with success; however USDA Forest Service J.W. Toumey Nursery has not used it in the past due to its generally higher C:N values and lower pH (Williams and Hanks 1976; Follett et al. 1981; Rose et al. 1995). Peat is not used as a soil amendment in the USDA Forest Service J.W. Toumey Nursery, but the nursery is uniquely located where peat can be acquired locally at a minimal cost. In the 1940’s large amounts of peat were mined from bogs to the east of the nursery, and have lain un-touched in piles since then. However, nursery personnel are worried about the 
impact of adding this acidic peat on soil $\mathrm{pH}$. Therefore, this study will examine the effects of using hardwood sawdust, pine sawdust, and peat as organic amendments on: 1) soil physical and chemical properties, and 2) the growth response of three bareroot species commonly grown at the USDA Forest Service J.W. Toumey Nursery: jack pine (Pinus banksiana), red pine (Pinus resinosa), and white pine (Pinus strobus). 


\section{Methodology}

\section{Study Site}

The study was conducted on the USDA Forest Service J.W. Toumey Nursery at Watersmeet, MI, T45N R39W Sec. 27 (46.2719 N, -89.1709 W) (Figure 1). The nursery soil is a Pence-Vilas loamy sand, and has supported rigorous seedling cultivation more than 70 years. Production consists largely of conifer species such as jack, red, and white pine seedlings; however, many other conifer and hardwood species are also grown. Most seedlings are grown on a four year rotation, three growing-seasons and one year for soil organic amendments and soil fumigation, while jack pine is on a three year cycle. Hardwood sawdust has been the organic amendment used for the past 25 years.

\section{Organic Amendments}

Four organic amendment treatments were chosen for this study: pine sawdust, hardwood sawdust, peat, and a non-amended control. For this study, specific information on the source of the hardwood sawdust used was not obtainable, but nursery personnel indicated that mills cutting sugar maple (Acer saccharum), red maple (Acer rubrum), quaking aspen (Populus tremuloides), and big-toothed aspen (Populus grandidentata) were the likely sources. Pine sawdust composed solely of red pine was supplied by Triple L Lumber, a small mill in Marengo, Wisconsin. Peat was mined from a bog on the nursery property, piled, and aged about 60 years. A tractor and a manure spreader were used to remove the peat and grind it into a manageable consistency suitable for application. 


\section{Amendment Application}

Each amendment was analyzed by the USDA Forest Service Rocky Mountain Research Station Laboratory at Moscow, Idaho for C and N (Table 1). The USDA Forest Service J.W. Toumey Nursery normally adds a $2.5 \mathrm{~cm}$ deep layer of hardwood sawdust to each bed one year before seeds are sown (every three to four years). Using a series of 0.3 $\mathrm{m}^{2}$ collection boxes in fields outside the study area, the hardwood sawdust application rate in concert with its $\mathrm{C}$ analysis was converted to total $\mathrm{C}$ applied. Once the $\mathrm{C}$ content of hardwood sawdust applied was determined, the quantities of pine sawdust and peat needed to add similar amounts of $\mathrm{C}$ were calculated and applied accordingly. All applications were checked in the field using the same collection boxes to determine the applied amounts and a second application was used to refine applications. All three amendments were added to each plot on August 3, 2006 (Table 2).

After amendments were applied, the standard nursery protocol of $141 \mathrm{~kg} / \mathrm{ha}$ of $\mathrm{N}$ $\left(\mathrm{NH}_{4} \mathrm{NO}_{3}\right)$ was added to each plot, and the entire area was ripped to an approximate 45 cm soil depth to break up any compaction layer that may have formed during the previous rotation and while adding the organic amendments. The study plots were then disked to a $20 \mathrm{~cm}$ depth to incorporate the amendments into the mineral soil.

\section{Soil Sampling}

\section{Nutrients}

Soils were sampled four times: 1) pre-treatment (July 11, 2006); 2) 10 days after treatment (August 14, 2007); 3) 11 months after treatment (June 20, 2007); and 4) 14 months after treatment (September 25, 2007). For each sample date, five $2.5 \mathrm{~cm}$ soil 
cores were taken randomly to a $20 \mathrm{~cm}$ soil depth from each plot, combined by plot, dried 24 hours at $105^{\circ} \mathrm{C}$, and sent to USFS Rocky Mountain Research Station Laboratory at Moscow, Idaho for analysis. In Moscow, all samples were sieved (2mm), split, and mechanically homogenized prior to analysis. SOM was determined by loss-on-ignition at $400^{\circ} \mathrm{C}$ for eight hours. Carbon and $\mathrm{N}$ were analyzed by dry combustion (at $1350^{\circ} \mathrm{C}$ for mineral soils, $1050^{\circ} \mathrm{C}$ for organics) (LECO CN2000, St. Joseph, Michigan). Potassium $(\mathrm{K})$, calcium $(\mathrm{Ca})$, and magnesium $(\mathrm{Mg})$ concentrations were determined on a $1 \mathrm{M}$ ammonium acetate extract (pH 7.0) (Perkin Elmer 5100PC Atomic Absorption Spectrometer, Waltham, Massachusetts). Soil pH was measured on a 1:2 soil to water sample.

\section{Soil Matric Potential}

Soil samples were collected from each plot to a soil depth of $20 \mathrm{~cm} 14$ months after treatments. All samples were dried 24 hours at $105^{\circ} \mathrm{C}$, transported to Michigan Technological University (MTU), and soil matric potentials were determined at $-10,-100$, -300 , and $-500 \mathrm{kPa}$ on ceramic plates in a pressure apparatus (Klute, 1986). Available water was then calculated using -10 and $-500 \mathrm{kPa}$ values, the latter used rather than the traditional -1500 kPa for permanent wilting point, because sandy soils, like those occurring at the study site, show little detectable difference at high stress levels (Brady and Weil 1999). 


\section{Seedlings}

\section{Establishment}

Using standard nursery protocol, white, red, and jack pine seeds were sown on May 31, June 4, and June 18, 2007 respectively. A layer of hardwood sawdust was then applied to prevent seed loss from predation, and wind and water erosion. This sawdust application was quantified using five, $0.3 \mathrm{~m}^{2}$ collection boxes per plot to determine the additional amounts of $\mathrm{C}$ and $\mathrm{N}$ applied to each plot (Table 3). Normal nursery practices, as outlined in Table 4, were conducted after all tree species were sown.

\section{Seedling Sampling}

At the end of the $1+0$ growing season (14 months after treatments), one seedling was carefully extracted from seven rows at three randomly selected subplots in each plot for a total sampling of 1008 seedlings ( 7 seedlings $\mathrm{x} 3$ subplots $\mathrm{x} 4$ treatments $\mathrm{x} 3$ species $\mathrm{x} 4$ replicates). One white pine plot was not sampled due to poor germination caused by problems with the mechanical seeder. A flat blade spade was used to ensure harvest of seedlings with complete root systems, which were placed in an ice chest, transported to MTU, and stored in a cold room $\left(2^{\circ} \mathrm{C}\right)$ until analysis.

In the laboratory, seedling roots were gently washed in cool tap water to remove lingering soil and sawdust. Stem diameter (at the root collar) and shoot height (from root collar to the top of the terminal bud) were measured on each seedling. The distance to the tallest terminal bud was recorded on forked seedlings. Seedlings were oven-dried 24 hours at $65^{\circ} \mathrm{C}$, cut at the root collar, and then roots and shoots weighed separately to determine the root to shoot ratio (R:S). Root and shoot portions were composited by plot, 
ground in a Wiley mill to pass a 40 mesh screen, and seedlings were sent to Pennsylvania State University - Agricultural Analytical Laboratory Services for nutrient analysis. Total N was determined using a Carlo Erba NA1500 (Thermo Fisher Scientific, Waltham, Massachusetts) or Elementar Vario Max N/C Analyzer (Elementar, Hanau, Germany) (Horneck and Miller 1998). All other plant tissue nutrients (N, P, K, Mg, Ca, S, Mn, Fe, Cu, B, Al, Zn, and Na) were determined using the dry ash method (Miller 1998).

\section{Statistical Analysis}

The statistical design was a factorial experiment (Cochran and Cox 1957). The seedling growth experiment had two factors, the soil amendment applied and seedling species, while the soil nutrient analyses added time as a third factor. The amendment factor has four treatments: control, pine sawdust, hardwood sawdust, and peat. The quantities of the amendment added to the soil were adjusted to provide equal amounts of organic C. The species factor had three treatments, jack, red, and white pine, which resulted in 12 (4 x 3) treatment combinations replicated 4 times for a total of $48(12 \times 4)$ plots (27.4 m long x 1.4 m wide). Soil nutrient samples were collected four times: 1) July 11, 2006 before the soil amendments were applied (pre-treatment), 2) 10 days, 3) 11 months, and 4) 14 months after amendments were applied.

Conducting the experiment in an operational nursery imposed several randomization restrictions on the application of treatments. The soil amendments were applied in strips crossing the rows of planted seedlings. There were six beds of seedlings, two for each species, and eight randomly selected strips of soil amendment application. 
The seedling species could not be randomized within each bed because of nursery management protocol. Wide buffers between plots and multiple sub-samples spread across each plot were used to reduce potential problems from this randomization restriction. Because the strips of amendment were applied across the experimental units of the tree species treatment, amendment was not randomized for each species of seedlings. This creates a split-plot experiment, where each strip of amendment application is the whole-plot observation for the amendment experiment. The split-plot treatments are the different beds of tree seedlings within a strip. For the split-plot treatment (species), each strip is a block in a completely randomized block design. For the amendment experiment, the eight strips are observations in a completely randomized design.

The nutrient flux measurements were repeated at four points over time. The soil sampled at each point in time was destructively sampled, eliminating the possibility of analyzing the data using repeated measures techniques. Instead, the measurements of nutrient content over time were treated as a split-plot over time component, with the whole-plot treatment being the species and soil amendment combination, and the splitplot treatment being the different sampling dates over the course of the experiment. The data were analyzed using Version 9.1 of the Statistical Analysis System with the General Linear Models procedure (Proc GLM). The probability of a type one error was set at 5\% $(\alpha=0.05)$. Tukey’s Honestly Significant Difference multiple range test was used to identify significantly different treatments within a factor. 


\section{Results}

Unless noted, no significant interactions were detected among amendments, date, and tree species for soil and seedling results. Results from the three tree species plots were combined for subsequent statistical analysis.

\section{Soil Chemical Properties}

\section{Soil Organic Matter and Carbon}

Soil in the hardwood sawdust-amended plots had significantly higher OM concentration than the control plots before the three amendments were applied ( $\mathrm{p}=$

0.035) (Figure 2A). However, this difference was much less than the differences detected after amendments were added, and appear to have little effect on SOM results. Addition of peat rapidly increased SOM 10 days after treatment $(\mathrm{p}=0.0001)$, while SOM concentration in both sawdust amendments increased more slowly (Figure 2B). However, large sawdust pieces may have been removed when the August 2006 soil samples were passed through a $2 \mathrm{~mm}$ sieve. Eleven months later (June 2007), these large sawdust pieces had likely decomposed enough to pass through the sieve (Figure 2C). In contrast, the peat was much finer than either sawdust, and very little was retained during sieving. Fourteen months after adding amendments, SOM in both sawdust-amended soils began to decrease, while SOM in the peat-amended soil remained high $(p=0.0001)$ (Figure 2D). Soils amended with either sawdust were not significantly different at any sampling date.

A significant increase in SOM was found in the control plots 11 months after treatment $(\mathrm{p}=0.017$ ) (Figure 3A), which was likely caused by the addition of hardwood 
sawdust (6.5 tC/ha) as a mulch to all beds after tree seeds were sown (June 2007). As expected, addition of peat and pine sawdust increased SOM 31\% $(\mathrm{p}<0.0001)$ and 17\% $(p=0.0002)$ after 14 months (Figure 3, B and D). Surprisingly, no significant change in SOM was found in the hardwood sawdust-amended plots $(\mathrm{p}=0.08)$ (Figure 3C). Because the hardwood sawdust has a lower C:N (280) than pine sawdust (650), the hardwood sawdust may have decomposed so quickly it was not detected in the study (Follett et al. 1981; Mexal and Fisher 1987). Peat used in this study had a C:N near 26 (similar to commercial peat), but is composed of more stable lignins than sawdust which impair decomposition, so it persists in the soil for long periods of time (Allison 1973; Wolstenholme and Whiley 2002).

In contrast to SOM, soil C levels in the control plots were not significantly different then in the amendment plots prior to amendment applications (Figure 4A). However, $C$ concentration in the pine sawdust plots was significantly lower $(p=0.03)$ than in the peat plots, but as noted with SOM, this initial difference appeared to have little effect on C results. After amendments were added in 2006, soil C in the sawdustamended soils increased more slowly than in peat-amended plots, probably because large pieces of sawdust were removed by 2 mm sieving (Figure 4, B and C). Overall, soil C response patterns were similar to SOM (Figure 5). The addition of peat and pine sawdust increased soil C concentrations 27\% (p=0.0006) and 21\% (p < 0.0001) after 14 months (Figure 5, B and D). However, soil C concentrations in both sawdust-amended plots decreased in the final sampling period, and no significant difference was detected between them and the control soil (Figure 4D). 


\section{Total Soil Nitrogen}

Total soil $\mathrm{N}$ in peat-amended plots was the highest throughout the study, being $32 \%$ to $38 \%$ higher than soils in the other treatments after 14 months $(\mathrm{p}<0.0001)$ (Figure 6). This was expected, as the peat amendment added large quantities of $\mathrm{N}$ (585 kg/ha), compared to $26 \mathrm{~kg} /$ ha in pine sawdust or $54 \mathrm{~kg} / \mathrm{ha}$ in hardwood sawdust (Table 2). Interestingly, total soil $\mathrm{N}$ in the peat-amended plots dropped significantly after 11 months $(p<0.0001)$ (Figure 7D). This may have been due to spring leaching, but this decrease was not detected in the other plots. The high C:N of sawdust will immobilize large amounts of available soil $\mathrm{N}$, and may have prevented $\mathrm{N}$ leaching in these soils (Mexal and Fisher 1987; Follett et al. 1981). Once routine fertilization treatments resumed the second year, total soil $\mathrm{N}$ in peat-amended plots increased significantly again $(\mathrm{p}<0.0001)$ (Table 5). Surprisingly, no significant changes were detected in control plots $(p=0.26)$, or those amended with either sawdust $(\mathrm{p}=0.45 ; \mathrm{p}=0.21)$ after fertilization resumed (Figure 7, A, B, and C). It is possible the higher CEC associated with peat was able to retain more $\mathrm{N}$ from the fertilizers than the other plots (Bollen 1969; Armson and Sandreika 1974), but no supporting data was collected.

\section{Soil Potassium, Calcium, and Magnesium}

Soil concentration of K, Ca, and Mg varied widely during the study. Peatamended soils had higher concentrations of exchangeable soil $\mathrm{K}$ than control or hardwood sawdust-amended soils after 14 months $(\mathrm{p}=0.04)$, but it was not reflected in seedling concentrations (Table 5 and 7). 


\section{Soil pH}

Soil pH ranged from 4.6 to 5.3, but no differences were detected among control and amended soils during any sampling period. Soil pH decreased at every sampling date, regardless of the amendment, with the last sampling period being significantly less than the pretreatment data $(\mathrm{p}<0.0001)$ (Figure 8). Natural acidification from OM decomposition or from fertilizer applications may have lead to the consistently lower $\mathrm{pH}$ levels (Munson 1983).

\section{Soil Matric Potential and Available Water}

Soil matric potential was significantly highest in peat-amended soils at all stress levels, $-10 \mathrm{kPa}(\mathrm{p}=0.006),-100 \mathrm{kPa}(\mathrm{p}=0.002),-300 \mathrm{kPa}(\mathrm{p}=0.01)$, and $-500 \mathrm{kPa}(\mathrm{p}=$ 0.004). The amount of water held in peat-amended soils was $21 \%$ higher at $-10 \mathrm{kPa}$, and 26\% higher at $-500 \mathrm{kPa}$, than in the control soils (Figure 9A). More importantly, the available water in peat-amended soils was greater than in control or those amended with hardwood sawdust (Figure 9B). Soils amended with pine sawdust were not significantly different from soils amended with peat.

\section{Seedling Response}

Species effects were not a central focus of this study. Species was included as a factor in the statistical models and explained substantial variability. Because species amendment interactions were not significant, the impact of the various amendments are uniform across the three species. 


\section{Growth}

Seedlings grown in peat-amended soils were significantly taller $(p=0.003)$ and had larger stem diameters $(\mathrm{p}=0.002)$ than seedlings grown in soils amended with either sawdust. However, the height and stem diameter of seedlings grown in control plots did not differ from those grown in peat-amended plots. Total biomasses of seedlings grown in control or peat-amended soils were significantly larger (30\% to $42 \%)$ than those grown in soils amended with either sawdust $(p=0.0003)$ (Table 6). These results may be due to the higher total soil $\mathrm{N}$ in peat-amended soils; however total soil $\mathrm{N}$ for un-amended soils was similar to both sawdust amendments (Figure 6D). No significant differences were seen in seedling $\mathrm{R}: \mathrm{S}(\mathrm{p}=0.10)$ (Table 6).

\section{Nutrient Concentration}

Seedlings grown in peat-amended soils had higher $\mathrm{N}$ concentrations than seedlings grown in pine sawdust-amended soils $(\mathrm{p}=0.02)$ (Table 7). Again, this may be due to the much higher amounts of $\mathrm{N}$ added in the peat amendment, which resulted in a 32\% higher level of total soil $\mathrm{N}$ than pine sawdust-amended soil (Figure 6D). However, $\mathrm{N}$ concentrations in seedlings grown in control and hardwood sawdust-amended soils were not significantly different from peat-amended or pine sawdust-amended soils (Table 7). Concentrations of $\mathrm{P}$ were significantly higher in seedlings grown in either sawdust treatment, as compared to those grown in control or peat-amended plots $(p=0.02)$ (Table 7). 


\section{Discussion}

\section{Soil Chemical Properties}

\section{Organic Matter and Carbon}

In this study, peat was the most effective organic amendment for increasing SOM; which was 27\% higher after 14 months. Munson (1983) also reported an increase in SOM of $40 \%$ after 18 months in a Florida nursery with a similar peat application rate. In contrast, two years after amending soils with nearly twice as much peat moss than applied in this study, Mexal and Fisher (1987) did not find any significant SOM differences in New Mexico. Mined peat may have lower nutrient concentrations than the commercial peat moss used by Mexal and Fisher, and may have slowed decomposition in this study. Although long-term effects of peat on SOM have yet to be studied in bareroot nursery applications, it has a greater potential to persist than most other forms of OM amendments added to tree nursery soils (May and Gilmore 1985).

Application of red pine sawdust raised SOM concentration by $21 \%$ after 14 months, similar to results reported by Munson (1983). However, Mexal and Fisher (1987) found no significant difference in SOM two years after applying pine sawdust. May and Gilmore (1985) found it took nearly five times as much pine sawdust, applied over a six-year period, to achieve similar rates of increase in SOM as achieved in this study. Larger increases may have been observed earlier in their study, but sawdust can decompose quickly, and no earlier results were presented. Even though sawdusts have a high C:N, their low lignin concentrations can allow for rapid decomposition (Davey 1984; Mexal and Fisher 1987). 
Although Starbuck (1994) reported a 95\% increase in SOM after amending soil with hardwood sawdust, the hardwood sawdust used in this study did not increase SOM content. Hardwood sawdust decomposes more rapidly than conifer sawdust due to its lower C:N. The short duration of Starbuck's study may explain the contradictory findings to this study, but further study is needed to support this hypothesis.

Williams and Hanks (1976) and Gulde et. al. (2007) indicated that soils may have an equilibrium SOM level or a $\mathrm{C}$ saturation point, above which higher values can not be maintained. This study was conducted on a sandy Pence-Vilas Complex soil, which normally contain between $0.5 \%$ and 3\% SOM (NRCS 2008). Pre-treatment SOM levels were near 3\%, and exceeded $4 \%$ in peat-amended soils after 14 months. The minimal response of SOM in these amended soils could be due to a C saturation point, although the actual level of this property in these soils requires further analysis.

\section{Total Soil Nitrogen}

As expected, peat-amended soils had higher concentrations of total $\mathrm{N}$ than the other treatments. Total $\mathrm{N}$ concentrations in soils amended with either sawdust were not different from the control soils. No other nursery studies were found that investigated the effect of sawdust additions on total soil N, however, Mexal and Fisher did find available soil $\mathrm{N}$ was rapidly depleted in sawdust-amended plots. Sawdust, of any species, is not recommended as an OM amendment due to its immobilization of soil N (Allison and Anderson 1951; Davey 1965; Armson and Sandreika 1974; Williams and Hanks 1976; Abd-el-malek et al. 1979; Cogger 2005). When low lignin, high C:N sawdust is consumed by soil microbes, available soil $\mathrm{N}$ is immobilized, which may result in growth- 
limiting $\mathrm{N}$ deficiencies. This loss of available $\mathrm{N}$ can begin as quickly as 40 days after application of sawdust with a high C:N ratio, or may take up to 160 days from sawdust with lower $\mathrm{C}: \mathrm{N}$ ratio. These $\mathrm{N}$ deficiencies can persist from one to four years or longer with high rates of sawdust application (Roberts and Stephenson 1948; Allison 1973). Consequently, large quantities of $\mathrm{N}$ need to be added with sawdust to offset this immobilization. Allison and Clover (1959) recommend adding $\mathrm{N}$ to sawdust until the amendment $\mathrm{N}$ concentrations reach $0.75 \%$ - 1\%. Although $141 \mathrm{~kg} / \mathrm{ha}$ of N (as 21-0-0) was added to the OM amendments in this study as part of the nursery routine fertilization program, amendment $\mathrm{N}$ concentrations (amendment + fertilizer) did not reach Allison and Clover’s recommendation (pine sawdust $0.4 \%$, hardwood sawdust $0.6 \%$, and peat 1.0\%). Even using Allison and Clover's conservative recommendation, the $\mathrm{N}$ fertilization rate used in this study was likely not high enough to offset $\mathrm{N}$ immobilization by sawdust.

\section{Soil Potassium, Calcium, and Magnesium}

No significant differences in exchangeable soil Ca or Mg were detected across any of our amendment treatments. May and Gilmore (1985) report a general increase in soil Ca and Mg from the addition of sawdust, but without statistical analysis. In this study, peat-amended soils did contain higher levels of exchangeable soil $\mathrm{K}$ than control or hardwood sawdust-amended soils. Mexal and Fisher (1987) did not detect any differences in soil K, while May and Gilmore (1985) reported a general increase in all three soil nutrients, but without statistical analyses. 


\section{Soil pH}

Soil $\mathrm{pH}$ decreased significantly in all treatments from a maximum of 5.3 to a minimum of 4.6 over the study duration. These values are still within the acceptable range for jack, red or white pine growth. Follett et al. (1981) and May and Gilmore (1984) also reported slight, but not specified, reductions in soil pH after addition of sawdust and peat. In contrast, Mexal and Fisher (1987) found no significant change in soil acidity, and speculated this was due to high levels of calcium carbonate buffering the $\mathrm{pH}$ of their study soils.

\section{Matric Potential and Available Water}

It is often stated that high levels of OM in nursery soil will increase soil water holding potential (Cogger 2005; Bollen 1969; Allison 1973; Rose et al. 1995; Christopher 1996; Jacobs et al. 2003; Riley and Steinfeld 2005). The results of this study indicated that addition of peat increased soil matric potential and available water after 14 months, but not with either red pine or hardwood sawdust. No other studies were found reporting specific results of the effects of soil amendments on matric potential or available water.

\section{Seedling Response}

Pine seedlings in this study grew poorer in soils amended with red pine sawdust and hardwood sawdust, as compared to seedlings grown in control soil (Table 9). However, the sawdust-amended soils contained similar amounts of total soil $\mathrm{N}$ as the control, and seedling $\mathrm{N}$ concentrations were within normal and acceptable ranges for each species (Armson and Sandreika 1974). The potential immobilization of soil 
nitrogen by sawdust may be responsible for this difference in growth. Starbuck (1994) found similar reductions in Forsythia spp. height growth after the addition of oak sawdust. May and Gilmore (1985) observed, but did not quantify, reduced growth after soil was amended with pine sawdust. In contrast, no growth differences were found when Mexal and Fisher (1987) added conifer sawdust or peat moss to ponderosa pine (Pinus ponderosa) seedlings. Mexal and Fisher indicated that the depletion of soil available $\mathrm{N}$ in sawdust-amended plots may have reduced seedling growth but the results were not significant. As discussed earlier, addition of sawdust lowers the amount of available soil N, which can reduce seedling growth. In future studies of this nature, available soil $\mathrm{N}$ data should be collected.

Seedlings grown in soils amended with peat grew significantly taller, had greater biomass, and had larger stem diameters than those grown in soils amended with either sawdust. This was expected as the peat amendment added large quantities of $\mathrm{N}$ to the soil. Similarly, the low C:N and high lignin content of peat does not create available soil $\mathrm{N}$ deficiencies from immobilization, as can occur with sawdust treatments. Control seedlings were not significantly different than those grown in soil amended with peat. A likely explanation is that available soil $\mathrm{N}$ concentrations in the control soil were sufficient to satisfy the $\mathrm{N}$ requirements of the small $1+0$ conifer seedlings in this study. As the $\mathrm{N}$ demand of the seedlings increases with size, it is expected seedlings in the peat-amended soil will outperform those in the un-amended soil, as suggested in other studies (e.g. Bollen 1969; Allison 1973; Armson and Sandreika 1974; Riley and Steinfeld 2005). Jacobs et al. (2003) reported an increase in Douglas-fir (Pseudotsuga menziesii) seedling height and stem diameter over control seedlings when applying a peat supplemented with 
pumice, perlite, vermiculite, and coco-fiber. The nutrient concentration of such a peat mixture may have been beneficial to seedling growth. Maxal and Fisher (1987) found no significant growth differences between ponderosa pine seedlings grown in soils amended with peat moss, sawdust, and the control. Again, this result may be related to the higher nutrient content and quicker decomposition rate of commercial peat moss.

The seedling R:S is important for out-planting success, the ultimate goal of a nursery (Jacobs et al. 2003). It is common to find higher R:S values in lower nutrient soils, as the seedlings increase root development in an attempt to acquire necessary nutrients (Paustain et al. 1992). Similar to other studies (Mexal and Fisher 1987; Jacobs et al. 2003), no difference in R:S of seedlings grown in any OM amended soil were found.

Seedling nutrient concentrations should reflect soil conditions (Follett et al. 1981) however, seedling nutrient concentrations from this study did not represent soil conditions as assumed. Total soil $\mathrm{N}$ differences were not reflected in seedling $\mathrm{N}$ concentrations. Seedlings grown in control soils had N concentrations similar to smaller seedlings grown in either sawdust-amended soil. This may be explained by the immobilizing effect of high C:N sawdust. Similarly, no other seedling nutrient concentrations reflected the soil conditions from which they were grown. No other studies were found which examined nutrient concentrations in both soil and seedlings. 


\section{Conclusions}

The results of this 14-month study at the USDA Forest Service J.W. Toumey Nursery on the effects of three organic amendments on soil properties and conifer seedling response showed that the addition of peat and pine sawdust increased SOM above an untreated control soil. However, the addition of hardwood sawdust did not result in any change in SOM concentration. Total soil $\mathrm{N}$ concentration, matric potential, and available water-holding capacity increased in the peat-amended soil, but not in soils where sawdust was added. Other chemical and physical properties were generally similar across the three organic amended and control soil after 14 months. Seedlings grew tallest, had the largest stem diameter, and obtained the greatest biomass in soil amended with peat, as compared to either sawdust treatment. Seedlings grown in the control soil were, however, as large as seedlings grown with peat additions, which may be a reflection on the low available $\mathrm{N}$ requirements of $1+0$ seedlings or the lack of $\mathrm{N}$ immobilization. No differences were detected in seedling R:S values among any soil amendment treatments. 


\section{Management Implications}

Hardwood sawdust has been used as the soil amendment in the USDA Forest Service J.W. Toumey Nursery for more than 25 years. This study found adding this sawdust to this sandy nursery soil had no significant effect on soil physical (matric potential and available water) or chemical properties (SOM, soil nutrients), and reduced seedling growth. The use of red pine sawdust did increase SOM compared with control soil, but also caused a seedling growth reduction. Peat mined on the nursery property, however, proved superior to both sawdust treatments in improving soil conditions and seedling growth. Interestingly, the lack of a soil amendment resulted in seedlings of similar size to those in peat-amended soils. Further investigation is needed to determine the reason for this seedling response.

Previously, hardwood sawdust was available for the cost of transportation to the nursery, but now is quite costly. Red pine sawdust is still available for only the cost of transportation. Peat is available at the nursery, and some cost would be required to prepare the peat for application. This cost is negligible compared to the cost of purchasing and transporting sawdust. Therefore, it is recommended that the nursery further explore the use of peat as a soil organic amendment. Continued monitoring of SOM is also recommended to determine how long the benefit of peat additions will last. It is possible the Pence-Vilas Complex soil on the nursery is near its maximum SOM concentration, and frequent OM additions may not be required. Further monitoring is needed to test this hypothesis. 


\section{Figures and Tables}

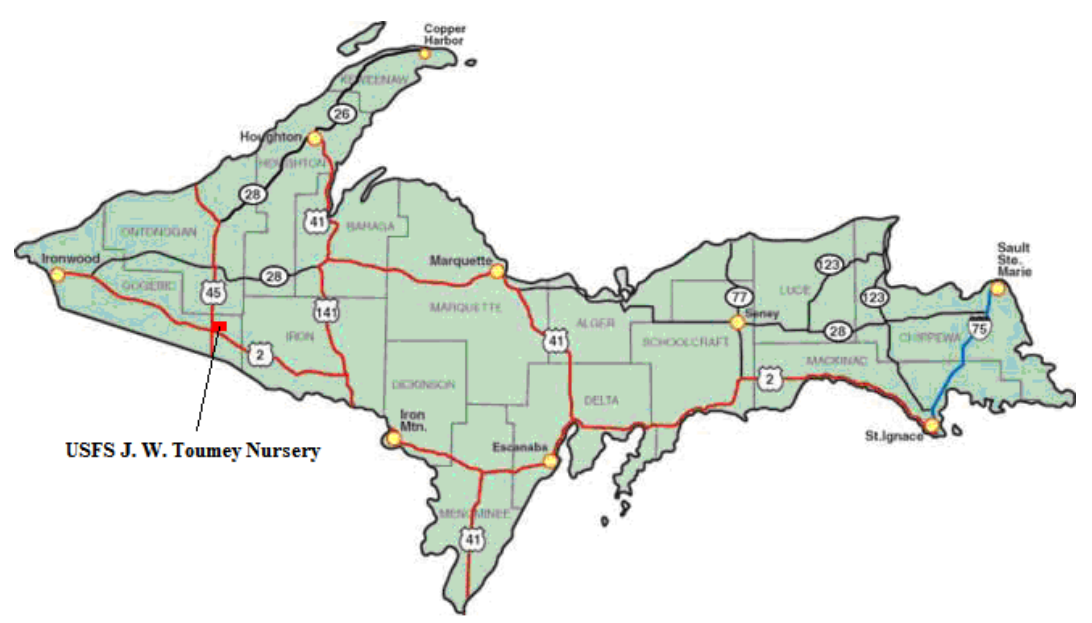

Figure 1: Location of the USDA Forest Service J.W. Toumey Nursery in Michigan’s Upper Peninsula (source data from www.data.geocomm.com) 

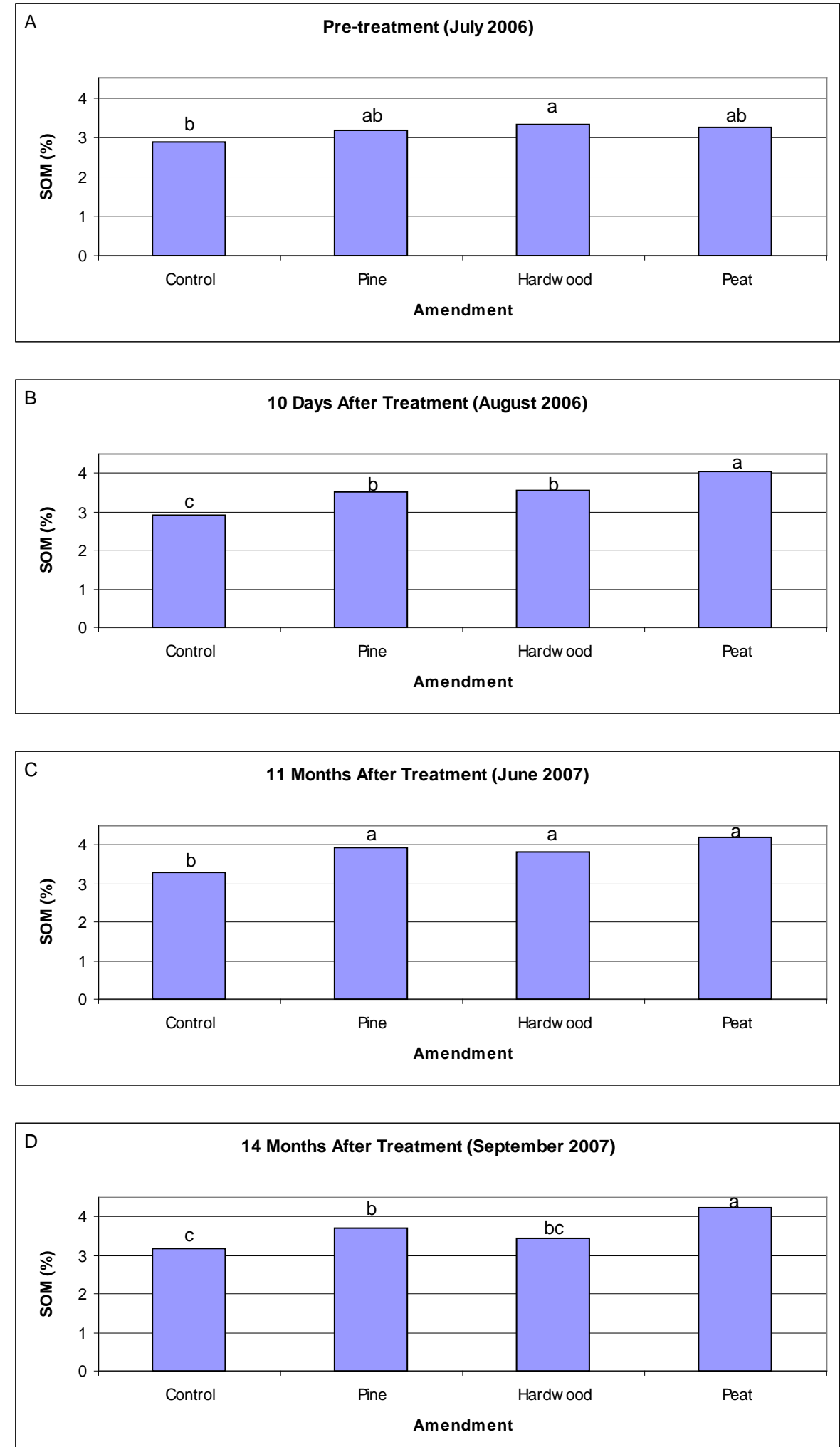

Figure 2: Differences in SOM concentration among control soil and soils amended with red pine sawdust, hardwood sawdust, and peat. (lowercase letters represent significant differences at $\mathrm{p}<0.05$ ) $(\mathrm{A}) \mathrm{p}=0.0346$, B) p $<0.0001$, C) $\mathrm{p}=0.0003$, and D) $\mathrm{p}<0.0001$ ) 

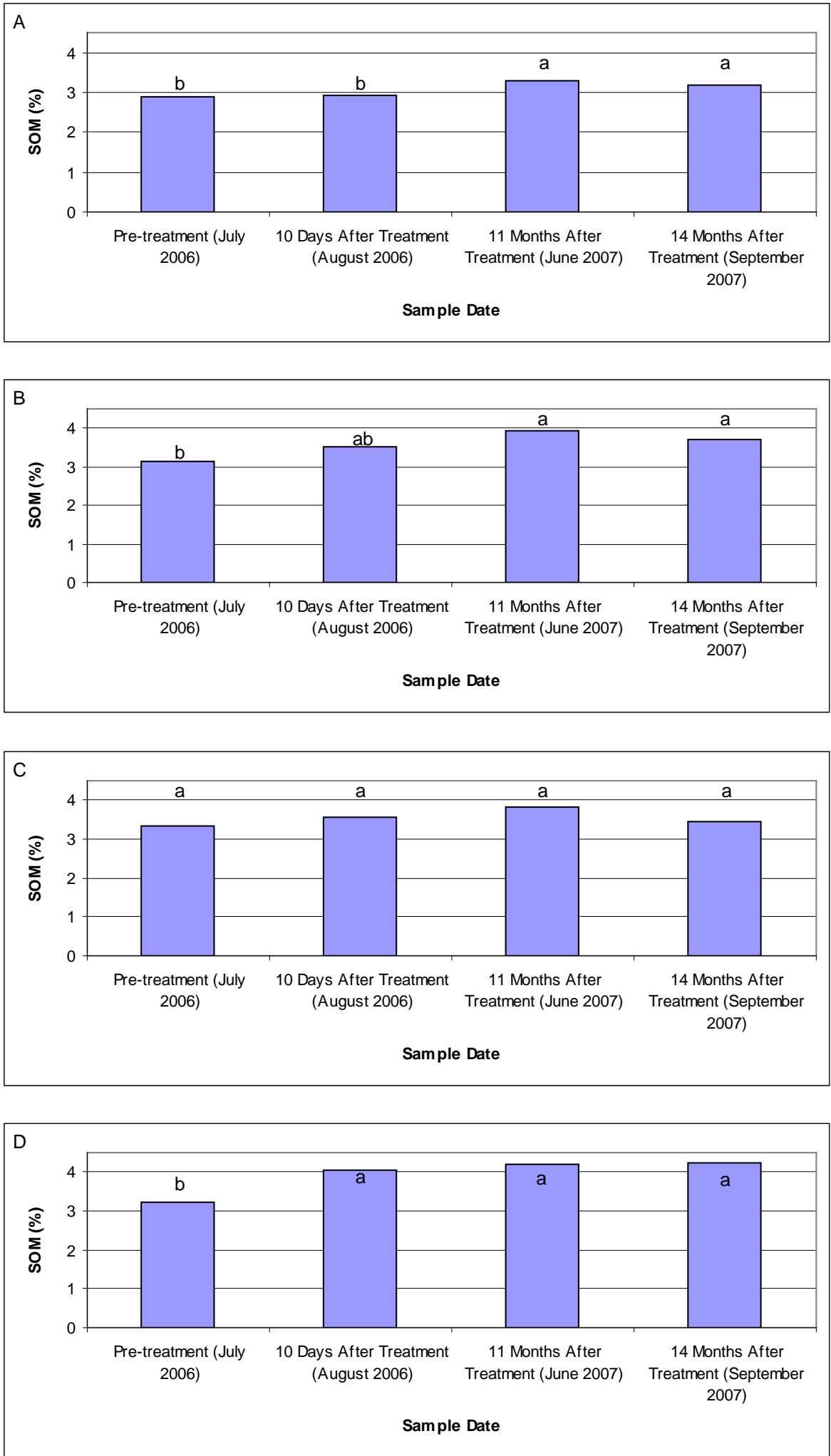

Figure 3: SOM concentrations before (pre-treatment), to 14 months after amending soil with nothing (control) (A), red pine sawdust (B), hardwood sawdust (C), and peat (D). (lowercase letters represent significant differences at $\mathrm{p}<0.05)(\mathrm{A}) \mathrm{p}<0.0001, \mathrm{~B}) \mathrm{p}=0.0002$, C) $\mathrm{p}=0.077$, and $\mathrm{D}) \mathrm{p}<0.0001$ ) 

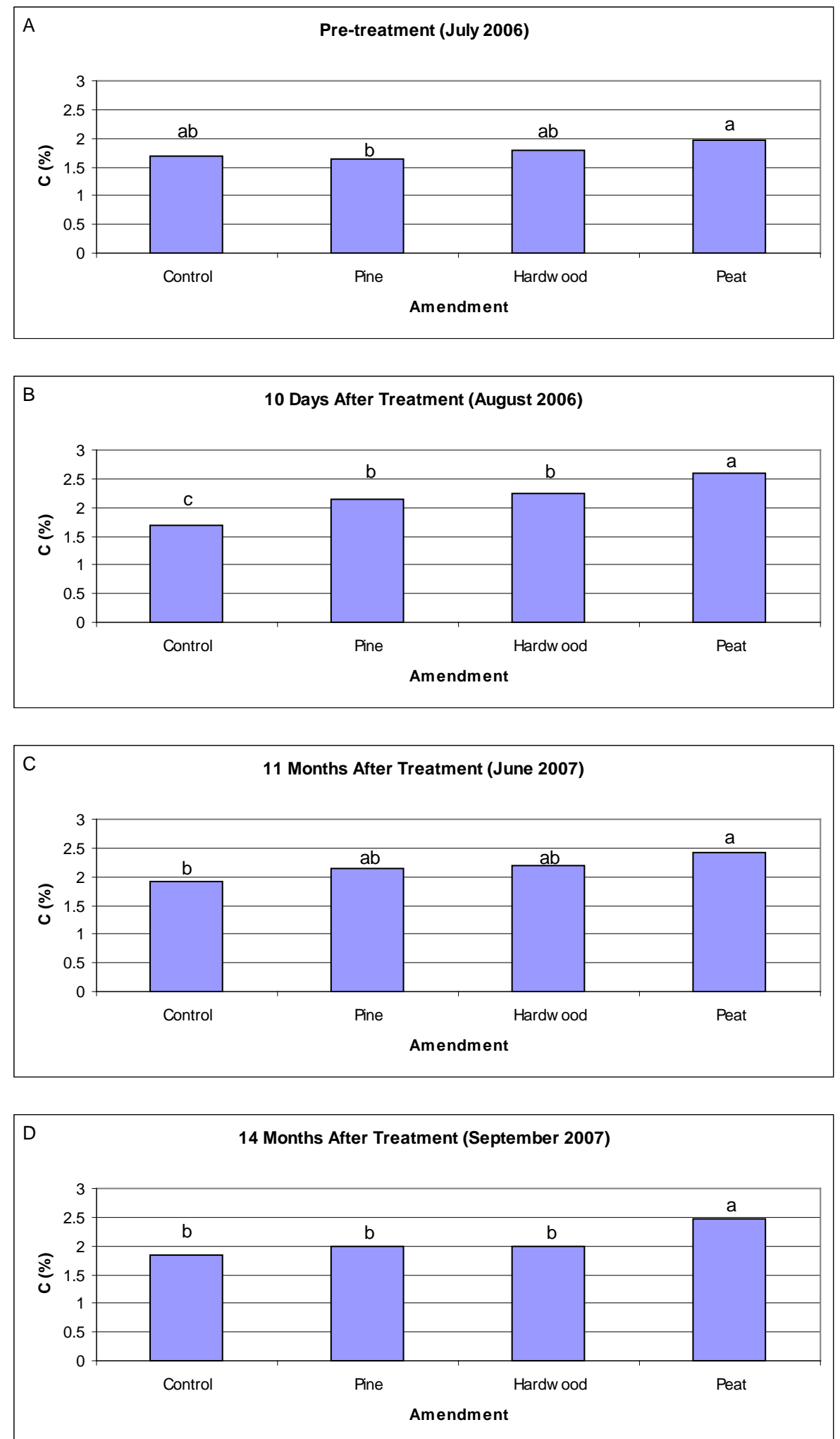

Figure 4: Differences in soil C concentration among control soil and soils amended with red pine sawdust, hardwood sawdust, and peat. (lowercase letters represent significant differences at $\mathrm{p}<0.05)(\mathrm{A}) \mathrm{p}=0.0265$, B) $\mathrm{p}<0.0001$, C) $\mathrm{p}=0.0016$, and D) $\mathrm{p}<0.0001$ ) 

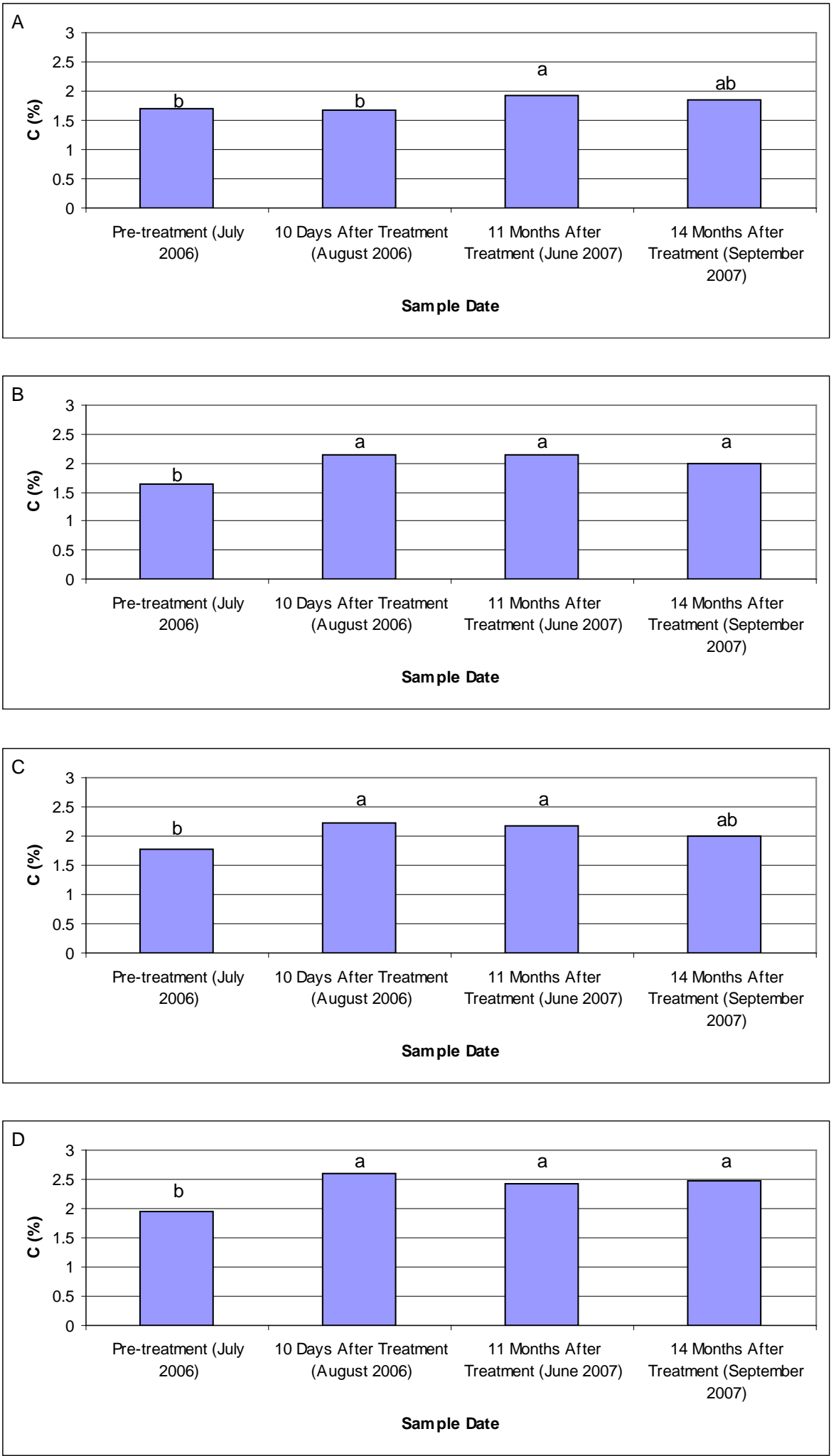

Figure 5: Soil C concentrations before (pre-treatment), to 14 months after amending soil with nothing (control) (A), red pine sawdust (B), hardwood sawdust (C), and peat (D). (lowercase letters represent significant differences at $\mathrm{p}<0.05)(\mathrm{A}) \mathrm{p}<0.0001$, B) $\mathrm{p}<0.0001$, C) $\mathrm{p}=0.0003$, and D) $\mathrm{p}=0.0006$ ) 

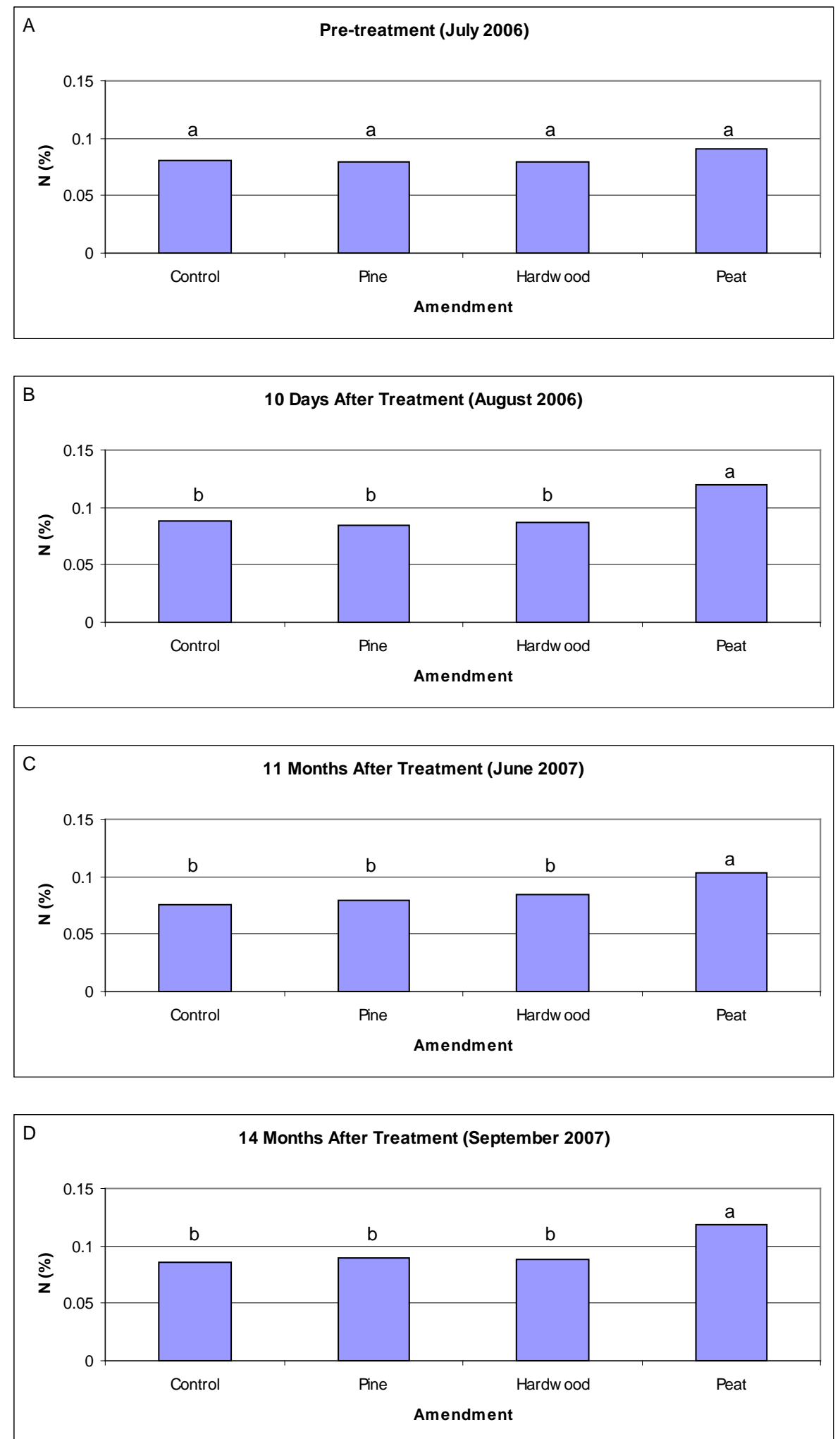

Figure 6: Differences in total soil $\mathrm{N}$ concentration among control soil and soils amended with red pine sawdust, hardwood sawdust, and peat. (lowercase letters represent significant differences at $\mathrm{p}<0.05$ ) (A) $\mathrm{p}$ $=0.274$, B) $\mathrm{p}<0.0001, \mathrm{C}) \mathrm{p}<0.0001$, and D) $\mathrm{p}<0.0001$ ) 

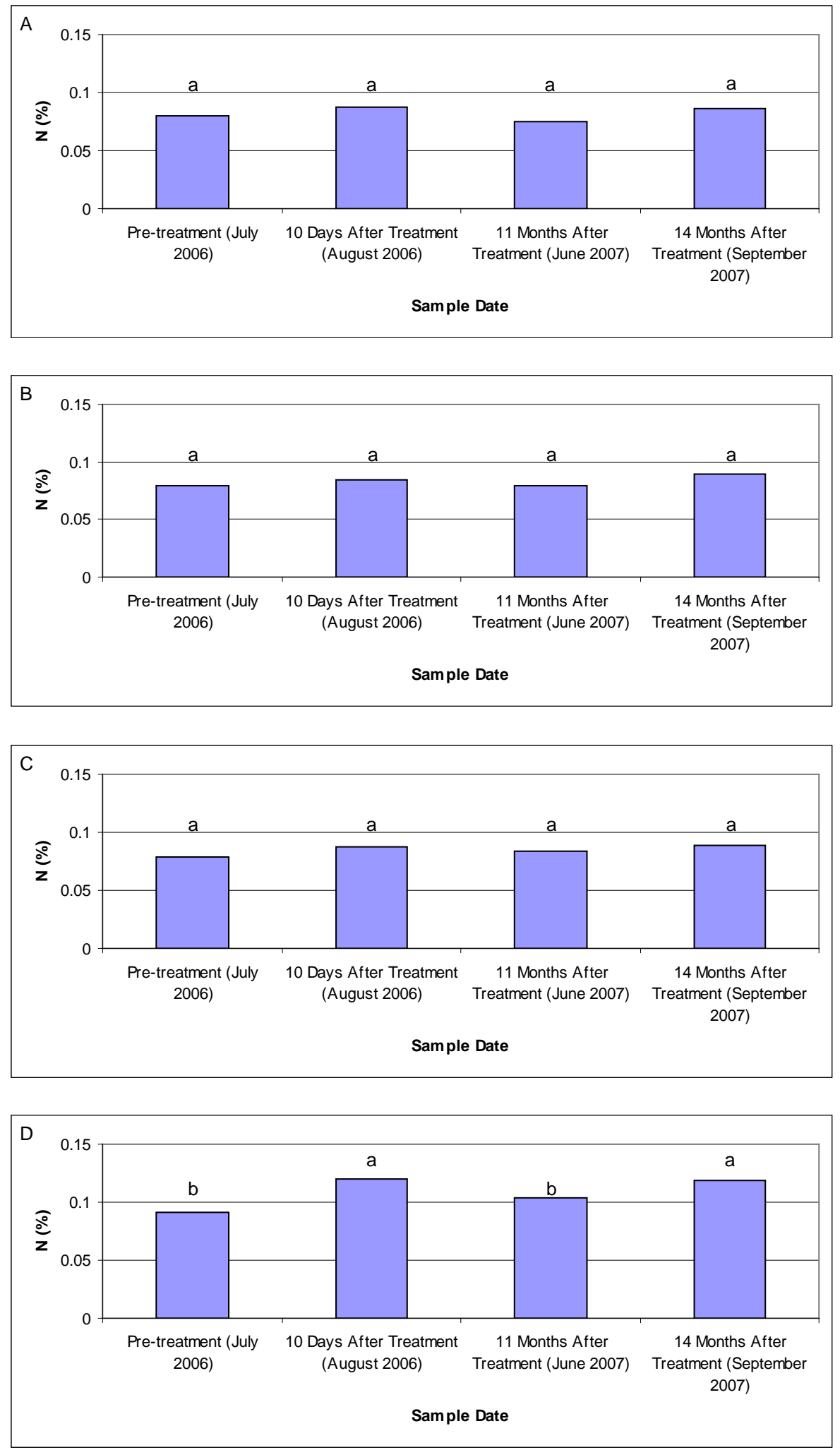

Figure 7: Total soil $\mathrm{N}$ concentrations before (pre-treatment), to 14 months after amending soil with nothing (control) (A), red pine sawdust (B), hardwood sawdust (C), and peat (D). (lowercase letters represent significant differences at $\mathrm{p}<0.05)(\mathrm{A}) \mathrm{p}=0.26, \mathrm{~B}) \mathrm{p}=0.45$, C) $\mathrm{p}=0.21$, and $\mathrm{D}) \mathrm{p}<0.0001$ ) 

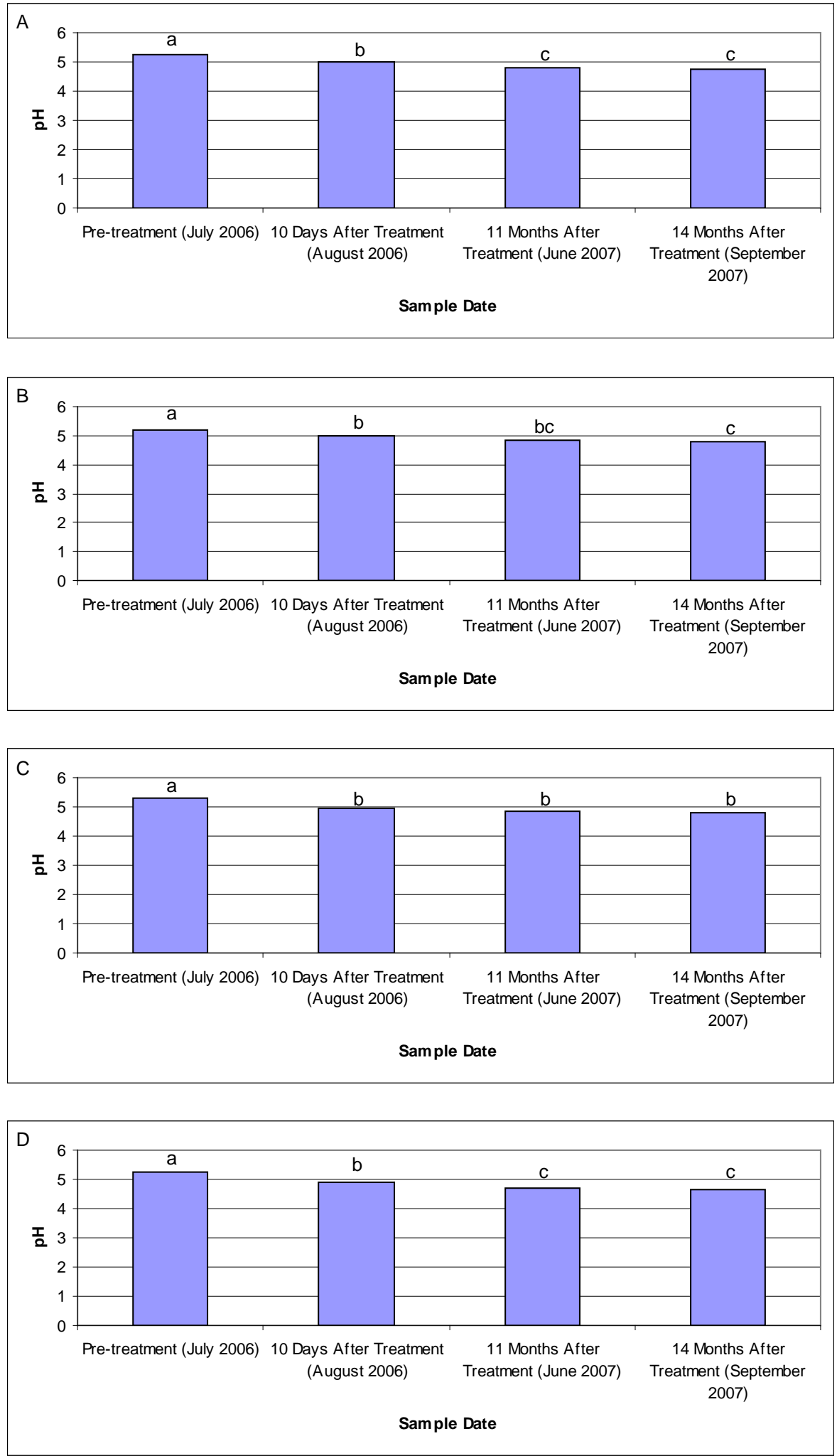

Figure 8: Soil pH before (pre-treatment), to 14 months after amending soil with nothing (control) (A), red pine sawdust (B), hardwood sawdust (C), and peat (D). (lowercase letters represent significant differences at $\mathrm{p}<0.05)(\mathrm{A}) \mathrm{p}=0.33, \mathrm{~B}) \mathrm{p}=0.23, \mathrm{C}) \mathrm{p}=0.01$, and $\mathrm{D}) \mathrm{p}=0.03$ ) 

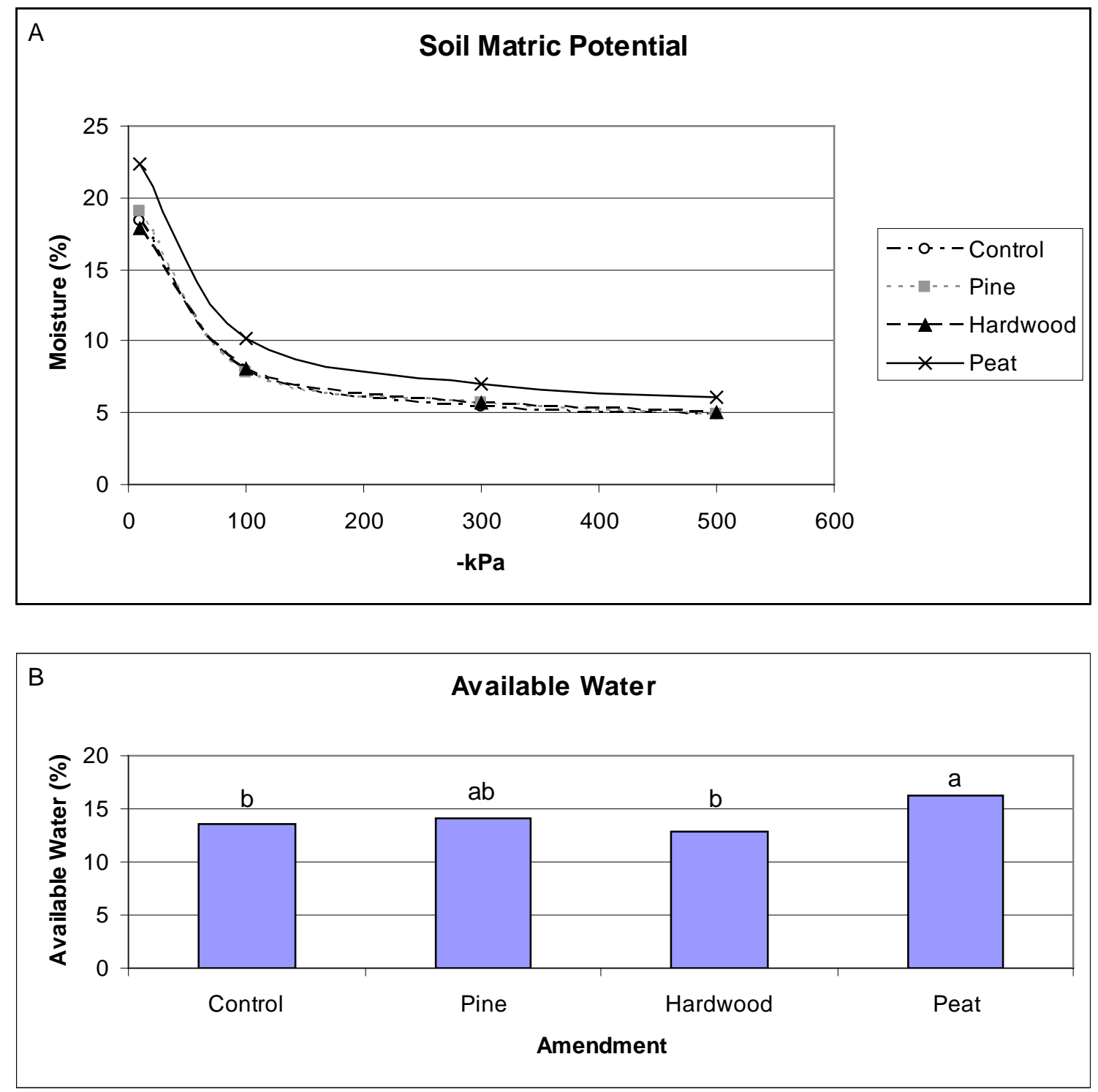

Figure 9: Matric potential (A) and available water (B) 14 months after amending soil with nothing (control), pine sawdust, hardwood sawdust, and peat. (lowercase letters represent significant differences at $\mathrm{p}<0.05)(\mathrm{A})-10 \mathrm{kPa} \mathrm{p}=0.006,-100 \mathrm{kPa} \mathrm{p}=0.002,-300 \mathrm{kPa} \mathrm{p}=0.01$, and $-500 \mathrm{kPa} \mathrm{p}=0.004$, and $\mathrm{B}) \mathrm{p}=$ $0.01)$ 
Table 1: Carbon and nitrogen concentration in three organic amendments added to the J.W. Toumey Nursery soil.

\begin{tabular}{|c|c|c|c|}
\cline { 2 - 4 } \multicolumn{1}{c|}{} & Conifer Sawdust & Hardwood Sawdust & Peat \\
\hline \% Carbon & 47.7 & 47.3 & 21.4 \\
\hline \% Nitrogen & 0.1 & 0.2 & 0.8 \\
\hline C/N & 653.0 & 283.0 & 27.0 \\
\hline
\end{tabular}

Table 2: Carbon and nitrogen application rates in organic amendments added to the J.W. Toumey Nursery in August 2006. All values in $\mathrm{kg} / \mathrm{ha}$

\begin{tabular}{|c|c|c|c|}
\hline (kg/ha of Carbon) & Conifer Sawdust & Hardwood Sawdust & Peat \\
\hline Application Rate & 17126 & 15166 & 15572 \\
\hline \% of Desired & $110 \%$ & $97 \%$ & $100 \%$ \\
\hline Actual Nitrogen Rate & 26.2 & 53.6 & 584.9 \\
\hline
\end{tabular}

Table 3: Rates of carbon and nitrogen in hardwood sawdust applied after tree seeds were sown (June 2007).

\begin{tabular}{|c|c|c|c|}
\hline Application Rate (kg/ha) & Jack Pine & Red Pine & White Pine \\
\hline Organic Matter & 13287 & 15007 & 13681 \\
\hline Carbon & 6278 & 7091 & 6464 \\
\hline Nitrogen & 22 & 25 & 23 \\
\hline
\end{tabular}

Table 4: Standard nursery procedures applied, by species, during the 2007 growing season

\begin{tabular}{|c|c|c|c|c|}
\hline Date & Beds & Application & Nutrient & Rate \\
\hline $8-7-06$ & All & $21-0-0$ & $\mathrm{~N}-0-0$ & $141.2 \mathrm{~kg} / \mathrm{ha}$ \\
\hline $5-31-07$ & All & Epsom Salt & $\mathrm{MgSO}_{4}$ & $112 \mathrm{~kg} / \mathrm{ha}$ \\
\hline $5-31-07$ & All & $0-0-50$ & $0-0-\mathrm{K}$ & $118 \mathrm{~kg} / \mathrm{ha}$ \\
\hline $6-10-07$ & All & Goal $2 \mathrm{XL}$ & Herbicide & $2.9 \mathrm{~L} / \mathrm{ha}$ \\
\hline $7-10-07$ & $3,4,5,6$ & $21-0-0$ & $\mathrm{~N}-0-0$ & $56 \mathrm{~kg} / \mathrm{ha}$ \\
\hline $7-17-07$ & $3,4,5,6$ & $0-0-022-22-11$ & $0-0-\mathrm{K}-\mathrm{S}-\mathrm{Mg}$ & $87 \mathrm{~kg} / \mathrm{ha}$ \\
\hline $7-18-07$ & All & $21-0-0$ & $\mathrm{~N}-0-0$ & $56 \mathrm{~kg} / \mathrm{ha}$ \\
\hline $7-22-07$ & All & Goal $2 \mathrm{XL}$ & Herbicide & $2.2 \mathrm{~L} / \mathrm{ha}$ \\
\hline $7-25-07$ & 1,2 & $0-0-22-22-11$ & $0-0-\mathrm{K}-\mathrm{S}-\mathrm{Mg}$ & $91 \mathrm{~kg} / \mathrm{ha}$ \\
\hline $7-26-07$ & All & $21-0-0$ & $\mathrm{~N}-0-0$ & $56 \mathrm{~kg} / \mathrm{ha}$ \\
\hline $7-29-07$ & All & Cleary's & Fungicide & $1.1 \mathrm{~kg} / \mathrm{ha}$ \\
\hline $8-1-07$ & All & $0-0-50$ & $0-0-\mathrm{K}$ & $128 \mathrm{~kg} / \mathrm{ha}$ \\
\hline $8-9-07$ & All & Goal $2 \mathrm{XL}$ & Herbicide & $0.68 \mathrm{~L} / \mathrm{ha}$ \\
\hline
\end{tabular}


Table 5: Soil cation concentrations before (pre-treatment), to 14 months after amending soil with nothing (control), red pine sawdust, hardwood sawdust, and peat. (lowercase letters represent significant differences at $\mathrm{p}<0.05$ )

\begin{tabular}{|c|c|c|c|c|c|}
\hline $\begin{array}{l}\text { Soil Nutrient } \\
\text { (mg/kg) }\end{array}$ & Amendment & $\begin{array}{l}\text { Pre-treatment } \\
\text { (July 2006) }\end{array}$ & $\begin{array}{c}10 \text { Days After Treatment } \\
\text { (August 2006) }\end{array}$ & $\begin{array}{l}11 \text { Months After Treatment } \\
\text { (June 2007) }\end{array}$ & $\begin{array}{c}14 \text { Months After Treatment } \\
\text { (September 2007) }\end{array}$ \\
\hline \multirow{5}{*}{ Potassium } & Control & $82.9 \mathrm{a}$ & $71.3 \mathrm{a}$ & $50.9 a$ & $49.1 b$ \\
\hline & Pine & $46.4 \mathrm{~b}$ & $76.1 \mathrm{a}$ & $68.4 \mathrm{a}$ & $68.2 \mathrm{ab}$ \\
\hline & Hardwood & $57.9 \mathrm{~b}$ & $68.1 \mathrm{a}$ & $52.0 \mathrm{a}$ & $61.4 \mathrm{~b}$ \\
\hline & Peat & $61.0 \mathrm{ab}$ & $80.7 \mathrm{a}$ & $68.6 \mathrm{a}$ & $74.7 \mathrm{a}$ \\
\hline & $p$-value & 0.0007 & 0.0996 & 0.6067 & 0.0159 \\
\hline \multirow{5}{*}{ Calcium } & Control & $471.3 \mathrm{a}$ & $440.2 \mathrm{a}$ & $375.2 \mathrm{a}$ & $416.1 \mathrm{a}$ \\
\hline & Pine & $426.4 \mathrm{a}$ & $447.9 \mathrm{a}$ & $394.2 \mathrm{a}$ & $417.2 \mathrm{a}$ \\
\hline & Hardwood & $407.9 \mathrm{a}$ & $461.3 \mathrm{a}$ & $398.0 \mathrm{a}$ & $436.4 \mathrm{a}$ \\
\hline & Peat & $417.7 \mathrm{a}$ & $468.5 \mathrm{a}$ & $427.8 \mathrm{a}$ & $444.8 \mathrm{a}$ \\
\hline & $p$-value & 0.1794 & 0.8446 & 0.2665 & 0.5532 \\
\hline \multirow{5}{*}{ Magnesium } & Control & $71.5 \mathrm{a}$ & $69.9 \mathrm{a}$ & $46.3 \mathrm{a}$ & $45.8 \mathrm{a}$ \\
\hline & Pine & $64.5 \mathrm{a}$ & $67.1 \mathrm{a}$ & $43.9 \mathrm{a}$ & $48.3 \mathrm{a}$ \\
\hline & Hardwood & $61.4 \mathrm{a}$ & $68.0 \mathrm{a}$ & $49.3 \mathrm{a}$ & $51.4 \mathrm{a}$ \\
\hline & Peat & $72.3 \mathrm{a}$ & $70.9 \mathrm{a}$ & $48.6 \mathrm{a}$ & $48.3 \mathrm{a}$ \\
\hline & $p$-value & 0.0514 & 0.8479 & 0.3687 & 0.2916 \\
\hline
\end{tabular}


Table 6: Morphologic traits of 1+0 seedlings grown in soils amended with nothing (control), pine sawdust, hardwood sawdust, and peat. Seedlings sampled 14 months after treatment from USDA Forest Service J.W. Toumey Nursery, Watersmeet, Michigan. (lowercase letters represent significant differences at $<<0.05$ )

\begin{tabular}{|c|c|c|c|c|c|}
\hline \multirow[b]{2}{*}{ Species } & \multirow[b]{2}{*}{ Amendment } & \multicolumn{4}{|c|}{ Morphologic Trait } \\
\hline & & Height (mm) & Stem Diameter (mm) & Root:Shoot & Biomass (g) \\
\hline \multirow{5}{*}{ Jack Pine } & Control & $61.7 \mathrm{a}$ & $1.39 \mathrm{a}$ & $0.42 \mathrm{a}$ & $0.32 \mathrm{a}$ \\
\hline & Pine & $54.2 \mathrm{a}$ & $1.13 \mathrm{~b}$ & $0.59 \mathrm{a}$ & $0.24 \mathrm{~b}$ \\
\hline & Hardwood & $53.3 \mathrm{a}$ & $1.12 \mathrm{~b}$ & $0.49 \mathrm{a}$ & $0.23 b$ \\
\hline & Peat & $59.2 \mathrm{a}$ & $1.31 \mathrm{ab}$ & $0.50 \mathrm{a}$ & $0.31 \mathrm{a}$ \\
\hline & $p$-value & 0.0434 & 0.009 & 0.3536 & 0.002 \\
\hline \multirow{5}{*}{ Red Pine } & Control & $51.4 \mathrm{a}$ & $1.12 \mathrm{a}$ & $0.51 \mathrm{a}$ & $0.25 \mathrm{ab}$ \\
\hline & Pine & $46.8 \mathrm{a}$ & $0.99 \mathrm{a}$ & $0.55 \mathrm{a}$ & $0.21 \mathrm{~b}$ \\
\hline & Hardwood & $48.6 \mathrm{a}$ & $1.00 \mathrm{a}$ & $0.54 \mathrm{a}$ & $0.20 \mathrm{~b}$ \\
\hline & Peat & $49.7 \mathrm{a}$ & $1.12 \mathrm{a}$ & $0.55 \mathrm{a}$ & $0.27 \mathrm{a}$ \\
\hline & $p$-value & 0.13 & 0.071 & 0.7265 & 0.0054 \\
\hline \multirow{5}{*}{ White Pine } & Control & $59.4 \mathrm{a}$ & $1.21 \mathrm{a}$ & $0.72 \mathrm{a}$ & $0.29 \mathrm{a}$ \\
\hline & Pine & $53.3 \mathrm{a}$ & $1.09 \mathrm{a}$ & $0.78 \mathrm{a}$ & $0.22 b$ \\
\hline & Hardwood & $52.9 \mathrm{a}$ & $1.06 \mathrm{a}$ & $0.71 \mathrm{a}$ & $0.21 b$ \\
\hline & Peat & $58.2 \mathrm{a}$ & $1.22 \mathrm{a}$ & $0.71 \mathrm{a}$ & $0.31 \mathrm{a}$ \\
\hline & $p$-value & 0.0246 & 0.0443 & 0.736 & 0.0006 \\
\hline \multirow{5}{*}{ Combined } & Control & $57.5 \mathrm{a}$ & $1.24 \mathrm{a}$ & $0.55 \mathrm{a}$ & $0.29 \mathrm{a}$ \\
\hline & Pine & $51.4 \mathrm{~b}$ & $1.07 \mathrm{~b}$ & $0.64 \mathrm{a}$ & $0.22 b$ \\
\hline & Hardwood & $51.6 \mathrm{~b}$ & $1.06 \mathrm{~b}$ & $0.58 \mathrm{a}$ & $0.21 b$ \\
\hline & Peat & $55.7 \mathrm{a}$ & $1.22 \mathrm{a}$ & $0.58 \mathrm{a}$ & $0.30 \mathrm{a}$ \\
\hline & $p$-value & 0.003 & 0.002 & 0.1022 & 0.0003 \\
\hline
\end{tabular}


Table 7: Nutrient concentration of 1+0 seedlings grown in soils amended with nothing (control), pine sawdust, hardwood sawdust, and peat. Seedlings sampled 14 months after treatment USDA Forest Service J.W. Toumey Nursery, Watersmeet, Michigan. (lowercase letters represent significant differences at $\mathrm{p}<0.05$ )

\begin{tabular}{|c|c|c|c|c|c|c|}
\hline \multirow[b]{2}{*}{ Species } & \multirow[b]{2}{*}{ Amendment } & \multicolumn{5}{|c|}{ Nutrient Concentration (\%) } \\
\hline & & $\mathbf{N}$ & $\mathrm{K}$ & $\mathbf{C a}$ & $\mathrm{Mg}$ & $\mathbf{P}$ \\
\hline \multirow{5}{*}{ Jack Pine } & Control & $2.35 a b$ & $0.94 \mathrm{a}$ & $0.31 \mathrm{a}$ & $0.14 \mathrm{a}$ & $0.27 \mathrm{~b}$ \\
\hline & Pine & $2.09 \mathrm{~b}$ & $0.92 \mathrm{a}$ & $0.32 \mathrm{a}$ & $0.15 \mathrm{a}$ & $0.29 \mathrm{a}$ \\
\hline & Hardwood & $2.25 \mathrm{ab}$ & $0.96 \mathrm{a}$ & $0.30 \mathrm{a}$ & $0.14 \mathrm{a}$ & $0.28 \mathrm{ab}$ \\
\hline & Peat & $2.44 \mathrm{a}$ & $0.93 \mathrm{a}$ & $0.31 \mathrm{a}$ & $0.14 \mathrm{a}$ & $0.28 \mathrm{ab}$ \\
\hline & $p$-value & 0.025 & 0.4501 & 0.3195 & 0.1029 & 0.0299 \\
\hline \multirow{5}{*}{ Red Pine } & Control & $2.18 \mathrm{a}$ & $0.91 \mathrm{ab}$ & $0.27 \mathrm{a}$ & $0.15 \mathrm{a}$ & $0.30 \mathrm{~b}$ \\
\hline & Pine & $2.08 \mathrm{a}$ & $0.92 \mathrm{ab}$ & $0.28 \mathrm{a}$ & $0.15 \mathrm{a}$ & $0.33 \mathrm{a}$ \\
\hline & Hardwood & $2.28 \mathrm{a}$ & $0.95 \mathrm{a}$ & $0.27 \mathrm{a}$ & $0.15 \mathrm{a}$ & $0.33 \mathrm{a}$ \\
\hline & Peat & $2.26 \mathrm{a}$ & $0.88 \mathrm{~b}$ & $0.27 \mathrm{a}$ & $0.14 \mathrm{a}$ & $0.29 \mathrm{~b}$ \\
\hline & $p$-value & 0.1071 & 0.0269 & 0.8479 & 0.1344 & 0.0005 \\
\hline \multirow{5}{*}{ White Pine } & Control & $1.99 \mathrm{a}$ & $0.75 a$ & $0.38 \mathrm{a}$ & $0.18 \mathrm{~b}$ & $0.30 \mathrm{a}$ \\
\hline & Pine & $1.92 \mathrm{a}$ & $0.75 \mathrm{a}$ & $0.37 \mathrm{a}$ & $0.19 \mathrm{a}$ & $0.35 \mathrm{a}$ \\
\hline & Hardwood & $2.1 \mathrm{a}$ & $0.79 \mathrm{a}$ & $0.38 \mathrm{a}$ & $0.19 \mathrm{a}$ & $0.35 \mathrm{a}$ \\
\hline & Peat & $2.11 \mathrm{a}$ & $0.76 \mathrm{a}$ & $0.38 \mathrm{a}$ & 0.18 b & $0.31 \mathrm{a}$ \\
\hline & $p$-value & 0.5943 & 0.7431 & 0.7543 & 0.0044 & 0.059 \\
\hline \multirow{5}{*}{ Combined } & Control & $2.17 \mathrm{ab}$ & $0.86 \mathrm{a}$ & $0.32 \mathrm{a}$ & $0.15 a b$ & $0.29 \mathrm{~b}$ \\
\hline & Pine & $2.03 \mathrm{~b}$ & $0.87 \mathrm{a}$ & $0.32 \mathrm{a}$ & $0.16 \mathrm{a}$ & $0.32 \mathrm{a}$ \\
\hline & Hardwood & $2.21 \mathrm{ab}$ & $0.9 \mathrm{a}$ & $0.32 \mathrm{a}$ & $0.16 \mathrm{a}$ & $0.32 \mathrm{a}$ \\
\hline & Peat & $2.27 \mathrm{a}$ & $0.86 a$ & $0.32 \mathrm{a}$ & $0.15 b$ & $0.29 b$ \\
\hline & $p$-value & 0.0199 & 0.0674 & 0.4313 & 0.0008 & 0.0001 \\
\hline
\end{tabular}


Table 8: The effect of soil organic amendments on soil organic matter and bareroot seedling growth. $(n s d=p>0.05)$

\begin{tabular}{|c|c|c|c|c|c|c|c|c|c|c|}
\hline \multirow[b]{2}{*}{ Amendment } & \multicolumn{2}{|c|}{ Rate } & \multirow[b]{2}{*}{ Time } & \multirow[b]{2}{*}{ Final SOM\% } & \multirow[b]{2}{*}{ SOM Increase } & \multicolumn{4}{|c|}{ Change in Plant Growth } & \multirow[b]{2}{*}{ Reference } \\
\hline & OM & tc/ha & & & & Height & Caliper & Biomass & R:S & \\
\hline Pine Sawdust & & 17.1 & \multirow{3}{*}{15 months } & 3.7 & $21 \%$ & $-11 \%$ & $-14 \%$ & $-23 \%$ & nsd & \multirow{3}{*}{ This Study } \\
\hline Hardwood Sawdust & & 15.2 & & 3.4 & nsd & $-10 \%$ & $-14 \%$ & $-26 \%$ & nsd & \\
\hline Peat & & 15.6 & & 4.2 & $27 \%$ & nsd & nsd & nsd & nsd & \\
\hline \multirow[b]{2}{*}{ Peat } & $22.4 \mathrm{t} / \mathrm{ha}$ & 12.0 & \multirow{5}{*}{1.5 years } & $1.7^{7}$ & $40 \%{ }^{9}$ & & & & & \multirow{5}{*}{ Munson, 1983} \\
\hline & $44.8 \mathrm{t} / \mathrm{ha}$ & 24.1 & & $1.9^{7}$ & $100 \%^{9}$ & & & & & \\
\hline-------- & $-89.6 \mathrm{t} / \mathrm{ha}$ & $\frac{48.1}{13.8}-$ & & $-\frac{3.0^{7}}{1.6^{7}}-$ & $-\frac{175 \%^{9}}{30 \% \%^{9}}--$ & & & & & \\
\hline \multirow[t]{2}{*}{ Pine Sawdust (20y old) } & $44.8 \mathrm{t} / \mathrm{ha}$ & 27.6 & & $2.1^{7}$ & $90 \%{ }^{9}$ & & & & & \\
\hline & $89.6 \mathrm{t} / \mathrm{ha}$ & 55.2 & & $3.0^{7}$ & $165 \%^{9}$ & & & & & \\
\hline Pine Sawdust & $43 \mathrm{t} / \mathrm{ha}$ & $21.5^{2}$ & \multirow{3}{*}{2 years } & $1.0-1.5$ & nsd & nsd & nsd & nsd & nsd & \multirow{3}{*}{ Mexal and Fisher, 1987} \\
\hline Peat Moss & $67 \mathrm{t} / \mathrm{ha}$ & $33.5^{2}$ & & $1.0-1.5$ & nsd & nsd & nsd & nsd & nsd & \\
\hline Composted Pine Bark & $67 \mathrm{t} / \mathrm{ha}$ & $33.5^{2}$ & & $1.0-1.5$ & nsd & nsd & nsd & nsd & nsd & \\
\hline \multirow{5}{*}{ Pine Sawdust } & $67.3 \mathrm{t} / \mathrm{ha}$ & $30.5^{1,2,5}$ & \multirow{5}{*}{6 years } & 2 & $0 \%{ }^{9}$ & & & & & \multirow{5}{*}{ May and Gilmore, 1985} \\
\hline & $134.5 \mathrm{t} / \mathrm{ha}$ & $61.0^{1,2,5}$ & & 2.2 & $0 \%{ }^{9}$ & & & & & \\
\hline & $100.9 \mathrm{t} / \mathrm{ha}$ & $45.8^{1,2,5}$ & & 2.2 & $10 \%{ }^{9}$ & & & & & \\
\hline & $201.8 \mathrm{t} / \mathrm{ha}$ & $91.5^{1,2,5}$ & & $2.5-2.6$ & $18 \%-25 \%^{9}$ & & & & & \\
\hline & $403.5 \mathrm{t} / \mathrm{ha}$ & $183.0^{1,2,5}$ & & 3.2 & $52 \%^{9}$ & & & & & \\
\hline Conifer Sawdust & & $60^{8}$ & 30 years & $3.4-3.5^{2}$ & $13 \%-15 \%$ & & & & & Paustain et. al., 1992 \\
\hline \multirow{2}{*}{$\begin{array}{l}\text { Fresh Oak Sawdust } \\
\text { Aged Oak Sawdust }\end{array}$} & $762 \mathrm{~m}^{3} / \mathrm{ha}$ & $61.0^{2,3}$ & \multirow{2}{*}{6 months $^{6}$} & 4.3 & $95 \%$ & $-40 \%$ & & & & \multirow{2}{*}{ Starbuck, 1994} \\
\hline & $762 \mathrm{~m}^{3} / \mathrm{ha}$ & $61.0^{2,3}$ & & 5.3 & $141 \%$ & $-31 \%$ & & & & \\
\hline \multirow{2}{*}{ Peat mix } & $118.1 \mathrm{~m}^{3} / \mathrm{ha}$ & $6.7^{2,4}$ & \multirow{2}{*}{2 years } & & & $9 \%{ }^{9}-13 \%$ & $8 \%^{9}-12 \%^{9}$ & nsd & nsd & \multirow{2}{*}{ Jacobs et. al., 2003} \\
\hline & $236.1 \mathrm{~m}^{3} / \mathrm{ha}$ & $13.5^{2,4}$ & & & & $12 \%$ & $8 \%{ }^{9}-10 \%{ }^{9}$ & nsd & nsd & \\
\hline
\end{tabular}

Notes

1 Assume published rate is dry weight

2 Assumed cabon content of OM is $50 \%$ by dry weight

Sawdust weight, $160 \mathrm{~kg} / \mathrm{m}^{3}$ (Rose, 1985)

Peat mix weight, 110 to $160 \mathrm{~kg} / \mathrm{m}^{3}$

5 Rate a total of annual applications over 6 years

6 Missouri growing season is 6 months

7 SOM\% estimated from figure

8 Rate a total of biannual applications of $3.97 \mathrm{tC} / \mathrm{ha}$

9 Statistical analysis needed to determine significance 


\section{Literature Cited}

Abd-el-Malek, Y, M Monib, I Hosny and SA Girgis (1979) Effect of Organic Matter Supplementation on Nitrogen Transformations in Soils. I. Chemical and Bacteriological Changes. Zentralbl. Bakteriol. Naturwiss. 134: 209-216.

Alexander, M (1961) Introduction to Soil Microbiology. New York, John Wiley and Sons.

Allison, FE (1973) Soil Organic Matter and its Role in Crop Production. New York, Elsevier Scientific.

Allison, FE and RG Clover (1959) Rates of Decomposition of Shortleaf Pine Sawdust in Soil at Various Levels of Nitrogen and Lime. Soil Science 89: 194-201.

Allison, FE and MS Anderson (1951) The use of Sawdust for Mulches and Soil Improvement. USDA Circ. 891: 1-19.

Armson, KA and V Sandreika (1974) Forest Tree Soil Management and Related Practices. Public Service Centre, Ontario Ministry of Natural Resources. Toronto, Ontario. p. 179,

Bollen, WB (1969) Properties of Tree Barks in Relation to Their Agricultural Utilization. Res. Pap. PNW77. Portland, OR., USDA Forest Service, Pacific NW Forest and Range Exp. Sta.:36.

Boyer, JN and DB South (1984) Forest Nursery Practices in the South. South. J. of Appl. Forestry. 8: 6775.

Brady, NC, and RR Weil (1999) The Nature and Properties of Soil: 12th Edition. Upper Saddle River, Prentice-Hall, Inc.

Christopher, TBS (1996) Stabilizing Effect of Organic Matter. URL: http://www.agri.upm.edu.my/ chris/as/om_stable.html (accessed 28 March, 2008).

Cochran, WG, and GM Cox (1957) Experimental Designs, John Wiley and Sons.

Cogger, C (2005) Home Gardener’s Guide to Soils and Fertilizers. Washington State University, Ext. Soil Scientist. p. 23.

Cooperband, L (2002) Building Soil Organic Matter with Organic Amendments, a Resource for Urban and Rural Gardeners, Small Farmers, Turfgrass Managers and Large-scale Producers. Madison, WI, University of Wisconsin - Madison. p. 13.

Davey, CB (1965) Functions and Management of Organic Matter in Forest Nursery Soil. Nursery Soil Improvement Sessions, New York, College of Forestry, Syracuse.

Davey, CB (1984) Chapter 9, Nursery Soil Organic Matter: Management and Importance. In: ML Duyea, and TD Landis (eds.) Forest Nursery Manual: Production of Bareroot Seedlings. Hague, Netherlands., Martinus Nijhoff/Dr W Junk Publishers: 81-86.

Davey, CB and HH Krause (1980) Functions and Maintenance of Organic Matter in Forest Nursery Soils. In: Abrahamson, LP, and DH Bickelhaupt (eds.) Proc., N. Am. Forest Tree Nurs. Soils Workshop., State University New York, Coll. Environ. Sci. and Forestry, Syracuse., p.130-165.

Davis, AS and DF Jacobs (2005) Quantifying Root System Quality of Nursery Seedlings and Relationship to Outplanting Performance. New Forests 30: 295-311. 
Davis, AS, DF Jacobs, KE Wightman and ZKD Birge (2006) Organic Matter Added to Bareroot Nursery Beds Influences Soil Properties and Morphology of Fraxinus pennsylvanica and Quercus rubra Seedlings. New Forests 31: 293-303.

FAO (1999) State of the World’s Forests 1999. U. N., Rome, Italy.

FAO (2001) State of the World's Forests 2001. U. N., Rome, Italy.

Follett, RH, LS Murphy and RL Donahue (1981) Fertilizers and Soil Amendments. Englewood Cliffs, NJ, Prentice Hall, Inc.

Frankel, SJ, JK Stone, MM Cram, SW Fraedrich, J Juzwik, DM Hildebrand and L James (1999) Progress Towards Alternatives to MeBr Fumigation in Bareroot Forest Nurseries in the United States. URL: http://www.ars.usda.gov/is/np/mba/july99/bareroot.htm (accessed 17 Oct. 2006).

Gulde, S, H Chung, W Amelung, C Chang and J Six (2007) Soil Carbon Saturation Controls Labile and Stable Carbon Pool Dynamics. Soil Sci. Soc. Am. J. 72: 605-612.

Hartley, MJ (2002) Rationale and Methods for Conserving Biodiversity in Plantation Forests. For. Ecol. Manage. 155: 81-95.

Holland, A (2008) Personal Communication. Watersmeet, MI: USDA Forest Service JW Toumey Nursery. Manager.

Horneck, DA and RO Miller (1998) Determination of total nitrogen in plant tissue. In: Kalra, YP (ed.) Handbook and Reference Methods for Plant Analysis. New York, CRC Press.

Jacobs, DF, R Rose, DL Haase and PD Morgan (2003) Influence of Nursery Soil Amendments on Water Relations, Root Architectural Development, and Field Performance of Douglas-fir Transplants. New Forests 26: 263-277.

Klute, A (1986) Chapter 26, Water retention: Laboratory Methods. In: Klute, A (ed.) Methods of Soil Analysis. Madison, WI: Soil Sci. Soc. Am.: 635-662.

Landis, TD (1984) Chapter 29, Problem Solving in Forest-Tree Nurseries with Emphasis on Site Problems. In: Duyea, ML and TD Landis (eds.) Forest Nursery Manual: Production of Bareroot Seedlings. Hague, Netherlands, Martinus Nijhoff/Dr W Junk Publishers: 307-314.

May, JT and AR Gilmore (1985) Continuous Cropping at the Stauffer Nursery in Alabama. South, D.B. (ed.) Proc. of the International Symposium on Nursery Management Practices for South. Pines. Montgomery, AL. p. 213-243.

Makuck, C (2008) Personal Communication. Watersmeet, MI: USDA Forest Service JW Toumey Nursery. Nursery Forester.

Mexal, JG and JT Fisher (1987) Organic Matter Amendments to a Calcareous Forest Nursery Soil. New Forests 4: 311-323.

Miller, RO (1998) High-Temperature Oxidation: Dry Ashing. In: Kalra, YP (ed.) Handbook and Reference Methods for Plant Analysis. New York, CRC Press. p. 53-56.

Moilenen, R (2008) Personal Communication. Watersmeet, MI: USDA Forest Service JW Toumey Nursery. Field Manager. 
Munson, KR (1983) Decomposition and Effect on pH of Various Organic Soil Amendments. Proc. 1982 South. Nursery Conference. USDA Forest Service Tech. Pub. R8-TP4.

NRCS (2008) Web Soil Survey. URL: http://websoilsurvey.nrcs.usda.gov/app/WebSoilSurvey.aspx (accessed 27 March, 2008).

Pandey, D and J Ball (1998) The Role of Industrial Plantations in Future Global Fiber Supplies. Unasylva 193: 37-43.

Paustain, K, WJ Parton and J Persson (1992) Modeling Soil Organic Matter in Organic-amended and Nitrogen-fertilized Long-term Plots. Soil Sci. Soc. Am. J. 56: 476-488.

Rentz, R (2005) Use of Cover Crops in Hardwood Production. In: Dumroese, RK, LE Riley and TD Landis, tech. cords. National Proc: Forest and Conservation Nursery Associations - 2004. Proc. RMRS-P-35. Fort Collins, CO: USDA Forest Service, Rocky Mountain Research Station. p. 28.

Riley, LE and D Steinfeld (2005) Effects of Bareroot Nursery Practices on Tree Seedling Root Development: an Evolution of Cultural Practices at J Herbert Stone Nursery. N. Forests 30: 107126.

Roberts, AN and RE Stephenson (1948) Sawdust and Other Wood Wastes as Mulches for Horticutural Crops. Oregon State Horticultural Soc. Proc. (Annu. Rep. 40). p. 28-35.

Rose, R, D Haase and D Boyer (1995) Organic Matter Management in Forest Nurseries: Theory and Practices. Corvallis, OR, Technology Cooperative, Oregon State University. p. 20-24.

Starbuck, C (1994) Applying Research in Forestry. Rep. 6. Using Sawdust as a Soil Amendment. Missouri Dep. of Conservation. p. 4.

Williams, RD and SH Hanks (1976) slightly revised (1994) Hardwood Nursery Guide. USDA Forest Service, Agriculture Handb. No. 473. p. 5.

Wolstenholme, BN and AW Whiley (2002) Importance of the Carbon: Nitrogen Ratio of Organic Materials in Managing Nitrogen in Avocado Soils. URL:

http://www.avocado.co.za/new/pages/Wolstenholme_C_N_Ratio.doc (accessed 20 Oct. 2007). p. 3. 